\title{
WestVirginiaUniversity
}

THE RESEARCH REPOSITORY @ WVU

Graduate Theses, Dissertations, and Problem Reports

2008

\section{Selenite removal using GAC based iron-coated adsorbents}

Ning Zhang

West Virginia University

Follow this and additional works at: https://researchrepository.wvu.edu/etd

\section{Recommended Citation}

Zhang, Ning, "Selenite removal using GAC based iron-coated adsorbents" (2008). Graduate Theses, Dissertations, and Problem Reports. 1953.

https://researchrepository.wvu.edu/etd/1953

This Thesis is protected by copyright and/or related rights. It has been brought to you by the The Research Repository @ WVU with permission from the rights-holder(s). You are free to use this Thesis in any way that is permitted by the copyright and related rights legislation that applies to your use. For other uses you must obtain permission from the rights-holder(s) directly, unless additional rights are indicated by a Creative Commons license in the record and/ or on the work itself. This Thesis has been accepted for inclusion in WVU Graduate Theses, Dissertations, and Problem Reports collection by an authorized administrator of The Research Repository @ WVU. For more information, please contact researchrepository@mail.wvu.edu. 


\title{
Selenite Removal Using GAC based Iron-Coated Adsorbents
}

\author{
Ning Zhang
}

\author{
Thesis submitted to the \\ College of Engineering and Mineral Resources \\ at West Virginia University \\ in partial fulfillment of the requirements \\ for the degree of \\ Master of Science \\ In \\ Civil Engineering
}

\author{
Lian-Shin Lin, Ph.D., Chair \\ Dianchen Gang, Ph.D. \\ Benoit Van Aken, Ph.D.
}

Department of Civil and Environmental Engineering

Morgantown, West Virginia

2008

Keywords: selenite removal, iron-coated GAC, adsorption isotherm, adsorption

kinetics

Copyright 2008 Ning Zhang 


\section{ABSTRACT \\ Selenite Removal Using GAC based Iron-Coated Adsorbents}

\section{Ning Zhang}

Removal of selenite from aqueous phase using iron-coated granular activated carbons (GAC) was investigated in this study. Five different types of GAC were used for iron coating by oxidizing ferrous chloride with sodium hypochlorite and tested for selenite removal. Nitrogen adsorption-desorption analyses indicated that BrunauerEmmett-Teller (BET) surface area, pore size, and pore volume deceased with the iron coating. The Darco $12 \times 20$ GAC was shown to be the most effective adsorbent among the five tested GACs after iron coating. Among the different concentrations used for iron coating, the Darco $12 \times 20$ GAC coated with $0.1 \mathrm{M}$ ferrous chloride achieved the highest selenite removal $(97.3 \%)$.

High removal efficiency of selenite occurred in a wide range of $\mathrm{pH}$ (i.e., 2 to 8), but the efficiency decreased when $\mathrm{pH}$ was higher than 8 . A range of initial selenium concentrations $(0.5,1$ and $2 \mathrm{mg} / \mathrm{L})$ at three temperature $\left(25,35,45^{\circ} \mathrm{C}\right)$ were used to examine the adsorption behavior of the Fe-GAC. Adsorption kinetics showed that selenite removal efficiency reached more than $90 \%$ after 6 -hour adsorption for initial selenium concentration of $2 \mathrm{mg} / \mathrm{L}$ and equilibrium was obtained after 48 hours. Activation energy was calculated to be $30.42 \mathrm{KJ} / \mathrm{mol}$. A pseudo-second-order kinetic model was found to characterize the adsorption kinetics well for all the initial selenium concentrations and temperatures tested $\left(R^{2} \geq 0.9969\right)$.

Adsorption isotherms for three different initial selenium concentrations were developed and the data generally fit the Langmuir model well $\left(R^{2} \geq 0.994\right)$. The adsorption capacity reached as high as $1.68 \mathrm{mg}$-Se/g-adsorbent at equilibrium for initial concentration of $2 \mathrm{mg} / \mathrm{L}$ at $25^{\circ} \mathrm{C}$. The Gibbs free energy was determined to be negative, indicating the spontaneous nature of the adsorption reaction. Oxyanion competitive adsorption showed that sulfate $(0.1-5 \mathrm{mM})$ barely affected selenite adsorption. Other anions (phosphate, silicate and carbonate) impact selenite adsorption to various degrees with phosphate completely excluded selenite adsorption at $5 \mathrm{mM}$. 


\section{ACKNOWLEDEMENT}

My greatest gratitude goes to my co-advisors, Dr. Lian-Shin Lin and Dr. Dianchen Gang, both of them showed great patience and undertook tremendous responsibility in supervising the completion of my whole project and thesis writing. Dr. Gang's experience in designing the experiments and Dr. Lin's profound knowledge had impressed me significantly, and I benefited a lot from them. Also their nice personality encouraged me a lot in finishing the project. It was with their encouragement and help that I could be confident in doing the whole job. I also would like to thank Dr. Van Aken for his time and serving on my committee.

I would like to thank the Center of Advanced Separation Technologies (CAST)

for its funding support of this study. The analyses of the BET surface area and pore size/volume were conducted in Dr. Darran Cairns' laboratory at West Virginia University and his assistance is greatly appreciated.

The same thanks go to my parents. During the process of my study in WVU, they devoted their love and generosity to me. In addition, I would like to thank my friends and fellow students: James Cunningham, Donglin Huang, Hang Li, and Yueshun Chen, who were always ready to help when I had difficulties in conducting my research.

Last but not least, my thanks go to all the other faculties and staffs in Civil and Environmental Engineering, WVU: Dr. Xinchao Wei, Dr. Karen Buzby, and Research Assistant Will Ravenscroft. Their help and assistance allowed me to finish my research smoothly. 


\section{TABLE OF CONTENTS}

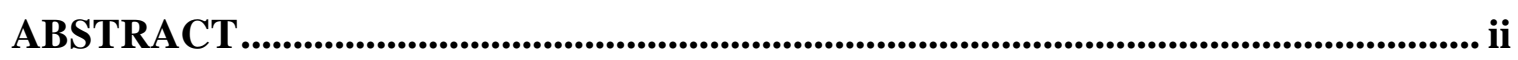

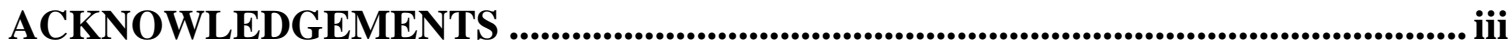

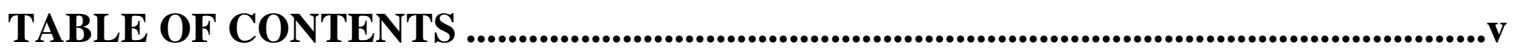

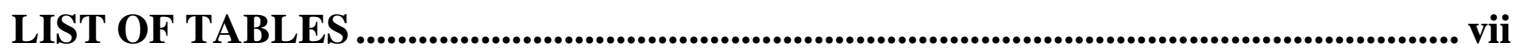

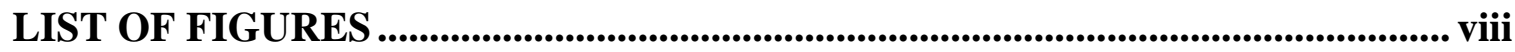

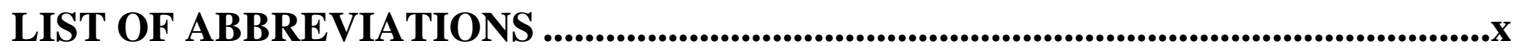

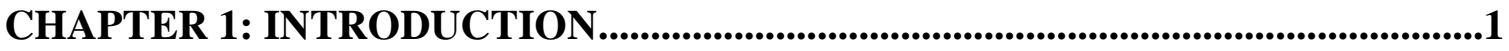

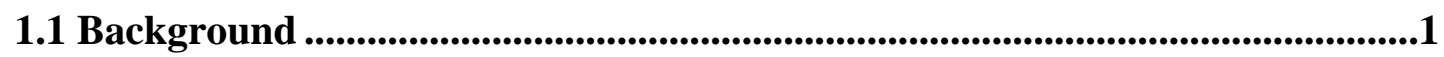

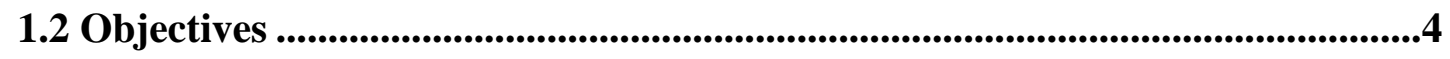

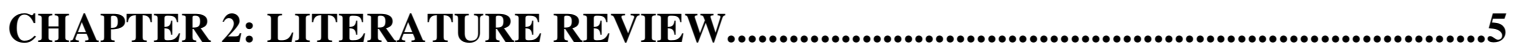

2.1 Occurrence .............................................................................................................................5

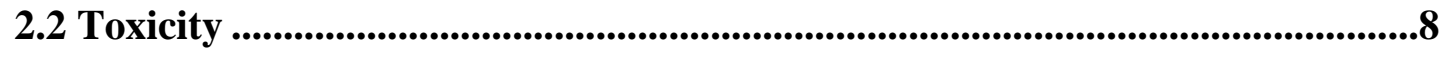

2.2.1 Acute Symptom ....................................................................................................8

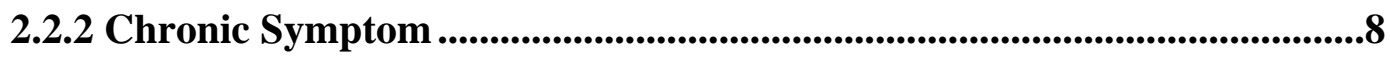

2.3 Selenium Reactions ................................................................................9

2.3.1 Selenium Oxidation-Reduction Reactions ...................................................9 
2.3.2 Se Sorption/Desorption Reactions .........................................................12

2.3.2.1 Sorption Reactions on Inorganic Materials .....................................12

2.3.2.2 Sorption Reactions on Organic Matter...........................................15

2.3.3 Selenium Complexation Reactions ..........................................................16

2.4 Selenium Treatment Technologies ...........................................................................17

2.4.1 Ion exchange

2.4.2 Chemical reduction with Zero-Valent Iron ..................................................18

2.4.3 Catalyzed Cementation of Selenium ...............................................................18

2.4.4 Biological Treatment ..........................................................................19

2.4.5 Ferrihydrite Adsorption of Selenium.................................................20

2.5 Background and Application of Activated Carbon ............................................20

2.5.1 Surface Structures of Activated Carbon........................................................20

2.5.2 Application of Activated Carbon............................................................21

2.5.3 Granular Activated Carbon Used in Adsorption Removal of Heavy Metal Pollutants .............................................................................................21

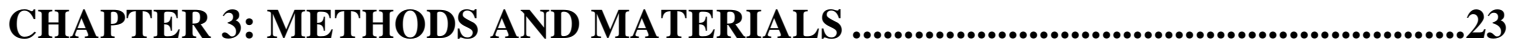

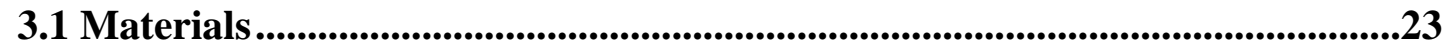

3.2 Adsorbent Preparation and Characterizations..........................................23

3.3 Selenium (III) Measurement...................................................................25

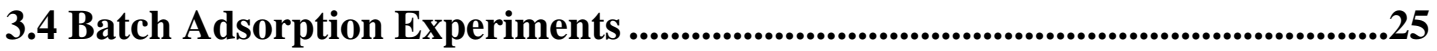


3.5 Adsorption Kinetics Experiments.

3.6 Adsorption Isotherm Experiments............................................................................28

3.7 Anion Competitive Adsorption................................................................................30

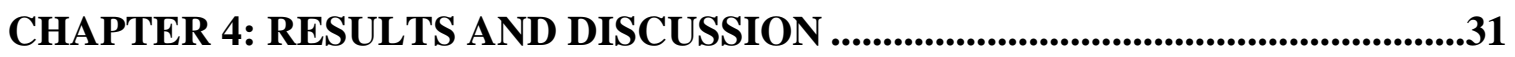

4.1 Best GAC experiment....................................................................................................31

4.2 Adsorbent Characterizations............................................................................32

4.3 Iron Concentration Effect...........................................................................................36

4.4 pH Effect.......................................................................................................................37

4.5 Kinetic Studies ...............................................................................................................39

4.6 Adsorption Isotherms..................................................................................................42

4.7 Anion Competition Adsorption .................................................................................48

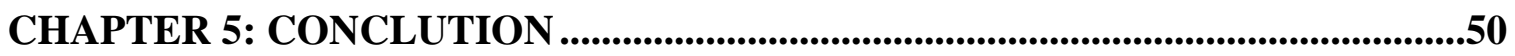

REFERENCES.....................................................................................................................52

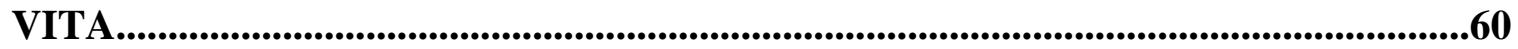




\section{LIST OF TABLES}

Table 1. Standard thermodynamic data used to establish the potential-pH diagram

(Séby, et al., 1998).

.10

Table 2. Surface and pore measurements for Darco 12x20 GAC.

Table 3. Values of the second-order adsorption rate constant $(k)$ and adsorption

capacity $\left(q_{e}\right)$ for selenite adsorption unto iron-coated (0.1 $\left.\mathrm{M} \mathrm{FeCl}_{2}\right)$ Darco 12x20

GAC in solutions with ionic strength of $0.1 \mathrm{M}$.

Table 4. Parameter values of the Langmuir model for selenite adsorption at

different temperatures............................................................................................................46

Table 5. Parameter values of the Langmuir model for selenite adsorption within

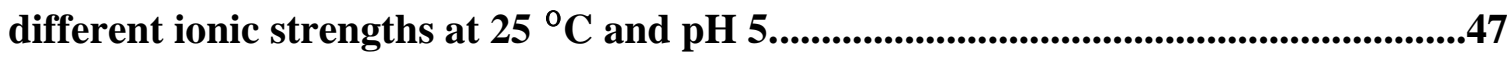




\section{LIST OF FIGURES}

Figure 1. Selenium production usage in each industry. .6

Figure 2. Selenium potential-pH diagram at $25^{\circ} \mathrm{C}$ for a dissolved selenium activity

of $10^{-7} \mathrm{~mol} / \mathrm{L}$ (Séby, et al., 1998)........................................................................... iii

Figure 3. Process of ferrous chloride coated onto GAC surface...............................24

Figure 4. Selenite adsorption using different amounts of Fe-GAC for isotherm

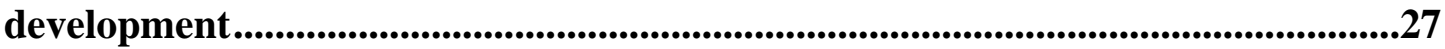

Figure 5. Selenite removal with various types of iron-coated (0.1 $\left.\mathrm{M} \mathrm{FeCl}_{2}\right) \mathrm{GACs} .31$

Figure 6. SEM micrographs for iron-coated Darco 12x20 GAC samples: (a) virgin

GAC, (b) coated by $0.02 \mathrm{M} \mathrm{FeCl}{ }_{2}$ and (c) coated with $0.1 \mathrm{M} \mathrm{FeCl}_{2}$ .34

Figure 7. Energy-disperse spectra of the virgin and iron coated Darco 12x20 GAC35

Figure 8. Effect of ferrous chloride concentration used for iron coating on selenite removal using Darco 12x20 GAC

Figure 9. Effect of $\mathrm{pH}$ on selenite removal iron-coated Darco 12×20 GAC (0.1 M

$\mathrm{FeCl}_{2}$ ) for the initial selenium concentration of $1 \mathrm{mg} / \mathrm{L}$ 
Figure 10. Adsorption kinetics and second-order kinetic model for selenium initial concentration of 2,1 and $0.5 \mathrm{mg} / \mathrm{L}$ at $\mathrm{pH} 5$ and $25^{\circ} \mathrm{C}$ with the adsorbent loading rate of $3,1.5$ and $0.8 \mathrm{~g} / \mathrm{L}$, respectively

Figure 11. Adsorption kinetics and second-order kinetic model for selenium initial concentration of $1 \mathrm{mg} / \mathrm{L}$ at different temperatures with the adsorbent loading rat of $1.5 \mathrm{~g} / \mathrm{L}$ at $\mathrm{pH} 5$

Figure 12. Selenite adsorption isotherms of $0.1 \mathrm{M}$ ferrous chloride coated Darco 12 $\times 20$ GAC for the initial selenium concentration of $2 \mathrm{mg} / \mathrm{L}$ at $\mathrm{pH} 5$ and $25^{\circ} \mathrm{C} \ldots 43$

Figure 13. The Langmuir isotherm model of $0.1 \mathrm{M}$ ferrous chloride coated Darco 12 $\times 20$ GAC for initial selenium concentration of $2 \mathrm{mg} / \mathrm{L}$ at $\mathrm{pH} 5$ and different temperatures

Figure 14. The Langmuir isotherm model of $0.1 \mathrm{M}$ ferrous chloride coated Darco 12 $\times 20$ GAC for initial selenium concentration of $1 \mathrm{mg} / \mathrm{L}$ with different ionic strengths at pH 5 and $25^{\circ} \mathrm{C}$

Figure 15. Effect of four oxyanions on selenite removal by iron-coated (0.1 M FeCl2) Darco 12×20 GAC coated after 24 hours at pH 5 and $25{ }^{\circ} \mathrm{C}$. Initial selenium concentration is $1 \mathrm{mg} / \mathrm{L}$ 


\section{LIST OF ABBREVIATIONS}

1. GAC - Granular activated carbon

2. SEM - Scanning electron microscopy

3. EDS - Energy dispersion spectrometer

4. BET - Brunauer-Emmett-Teller

5. DAN - 2, 3-diaminonaphthalene

6. MCL - Maximum contaminant level

7. MCLG - Maximum Contaminant Level Goals

8. EPA - Environmental Protection Agency

9. BDAT - Best demonstrated available technology

10. BASBR - Baffled anaerobic solids bed reactors

11. BSeR - Biological selenium reduction

12. HFO - Hydrous ferric oxide 


\section{CHARPTER 1: INTRODUCTION}

\subsection{Background}

In recent years, the increasing release of toxic metals from industrial waste such as arsenic, barium, cadmium, chromium, copper, lead, mercury, nickel, selenium, silver and zinc into natural waters is causing considerable concern. One of the most important toxic elements is selenium (Se). Selenium is an essential micronutrient for humans and animals. In plants, it occurs as a bystander mineral. In humans, selenium is a trace element nutrient which functions as cofactor for reduction of antioxidant enzymes such as glutathione peroxidases and thioredoxin reductase. However, accumulation of selenium in soils, aquifer sediments and drinking water through various pathways has threatened the health of plants, wildlife, and humans (Lakin, 1973). It degrades water quality and gets into the food chain, where it accumulates in fish and birds. Even though selenium contamination does not result in sudden fish kills, it causes deterioration and deformity in fish and wildlife over time, working almost invisibly. In some contaminated areas, high levels of selenium accumulation in plants, high rates of mortality and deformity in birds were observed (Bowen, 1966; Ohlendorf, 1989).

Selenium is widely used in industrial productions including the photocopy, glass and ceramic manufacture. It is also one of the strongly enriched elements in coal, being present as an organoselenium compound, a chelated species, or as an adsorbed element (USEPA, 2006). Coleman et al. (1993) reviewed the Se data from 9000 coal samples throughout the U.S. and found the highest concentrations of selenium in coal were in Texas and Mississippi. In West Virginia, a survey of trace elements in whole coals 
showed that selenium exhibits a wide range of concentration with an average of $4.2 \mathrm{mg} / \mathrm{L}$ with highest levels in Kanawha and Allegheny Formations (WVGES, 2006). Mountaintop removal and excess spoil valley fills were found to have impacts on the nearby waterways. In 2002, USEPA conducted a study of the stream chemistry associated with sites classified as mined, unmined, filled, and filled/ residence. Of the streams samples, selenium concentrations were found to exceed EPA's water quality criterion $(5 \mu \mathrm{g} / \mathrm{L})$ at most (13 out of 15$)$ sites in filled category (USEPA, 2003). Other main contamination sources of selenium were listed below (United States Department of Agricultural, 2002):

- Coal, gold, silver, nickel, and phosphate mining

- Metal smelting

- Municipal landfills

- Oil transport, refining, and utilization

- Agricultural irrigation

Selenium is chemically similar to sulfur, a group VI non-metal, which forms oxyacids of strengths similar to those of sulfur (Ghosh, et al. 1994). In the environment, selenium exists in different oxidation states, elemental selenium $\left(\mathrm{Se}^{0}\right)$, selenite $\left(\mathrm{SeO}_{3}{ }^{2-}\right)$, selenide $\left(\mathrm{Se}^{2-}\right)$, and selenate $\left(\mathrm{SeO}_{4}{ }^{2-}\right)$ (Tamari, 1998). It can also be present under the form of various organically bound $\mathrm{Se}^{2-}$ and these compounds are analogous to those of sulfur and include seleno-amino acids (i.e. selenocysteine and selenomethionine) and methyl selenides (i.e. dimethylselenide and dimethyldiselenide) (Séby et al., 1998). Selenite and selenate are thermodynamically stable under the $\mathrm{pH}$ and redox conditions 
and are the predominantly chemical forms in aqueous medium (Jacobs, 1989). Selenite is present in mildly oxidizing, neutral $\mathrm{pH}$ environments and typical humid regions, while selenate is the predominant form under ordinary alkaline and oxidized conditions (Goh and Lim, 2004).

Most of the selenium research conducted currently has focused on either agricultural drainage water or western U.S. coal mines (Vesper et al., 2004). A variety of treatment technologies have been reported in the literature for selenium removal (Mariñas and Selleck, 1992; Gallup, 1996; Frankenberger Jr. et al., 2004; Mavrov et al., 2006). Examples include ion-exchange, reverse osmosis, nanofiltration, solar ponds, chemical reduction with iron, microalgal-bacterial treatment and biological treatment. While these approaches can remove selenium to below $5 \mu \mathrm{g} / \mathrm{L}$ under optimal conditions, however, most of these systems are expensive, not suitable for mining wastewater with high concentration of sulfate. Therefore, there is a need for developing a treatment method suitable for removing selenium originated from mining activities. Adsorption of Se by metal oxides such as iron oxides and aluminum oxide has been demonstrated by several researchers (Ghosh et al., 1994; Parida, 1997; Su and Suarez, 2000; Monteil-Rivera et al., 2000), but theses adsorbents can be difficult to use in continuous flow systems due to their small particle size. To overcome this difficulty several researchers have combined iron oxides with more traditional adsorbents (i.e. sand and granular activated carbon) (Lo and Chen, 1997; Kuan et al., 1998; Namasivayam and Prathap, 2006). Granular activated carbon (GAC) is one of the most promising adsorbents.

It is well understood that there are several functional groups distributed on the surface of GAC, such as carboxyl, hydroxyl, phenol, and quinone. The structure of GAC 
can be described as a combination of carbon particles connected with a random distribution of these surface functional groups (Pakula et al., 1998). Fe (III) was demonstrated to form stronger complexation with ligands such as carboxyl and phenol groups than Fe (II), it is apparent that ferric should be more effective than ferrous in the complexation formation procedure ( $\mathrm{Gu}$ et al., 2005). The iron coated GAC over other adsorbents is expected to achieve higher metal removal and as well as removal of organics simultaneously, it is also easier to be applied to continuous heavy metals treatment (Vaughan Jr. and Reed, 2005). Gu et al. (2005) has successfully used Fe-GAC for removing arsenate from drinking water.

\subsection{Objectives}

The objective of this study was to develop and characterize an iron-coated GAC adsorbent which can be applied to selenite removal from waste water streams. Selenite $\left(\mathrm{SeO}_{3}{ }^{2-}\right)$ is believed to be more mobile and readily transported in groundwater than other selenium forms (Parida et al., 1997). It is also known to be more strongly bound to the sorbents than selenate $\left(\mathrm{SeO}_{4}{ }^{2-}\right)$ (Hingston et al, 1974). Five different GACs were selected and tested for the removal efficiency after coated with ferrous chloride. A series of batch adsorption experiments were conducted to determine the effect of $\mathrm{pH}$, iron to GAC ratio, reaction time, ionic strength, temperature and initial concentration of selenium on the removal efficiency of selenite. Effect of co-existing competitive anions (i.e. $\mathrm{SO}_{4}{ }^{2-}, \mathrm{SiO}_{3}{ }^{2-}$, $\mathrm{CO}_{3}{ }^{2-}$ and $\mathrm{PO}_{4}{ }^{3-}$ ) was also studied. 


\section{CHARPTER 2: LITERATURE REVIEW}

\subsection{Occurrence}

Selenium is a non metallic chemical element, member of the group XVI of the periodic table. Selenium occurs naturally in the environment. Though it is among the rare elements on the surface of the earth, selenium is widely dispersed in nature with a $1.3 \times 10^{-5} \%$ concentration in the earth's crust (Todini and Co s.p.a., 2006). There are a number of allotropic forms of selenium existing on the earth: the most popular are a red amorphous powder, a red crystalline material, and a gray crystalline metal-like form called metallic selenium. This last form conducts electricity better in the light than in the dark and is used in photocells. Selenium burns in air and is un-effected by water, but dissolves in concentrated nitric acid and alkalis.

Production of selenium in 1985 was reported to be 429,515 pounds (EPA, 2006). Its main application in industry includes electronic and photocopier components, gas manufacturing, chemical and pigments and others. Figure 1 illustrates the percentage of each industrial usage. 


\section{Selenium productiong usage demand}

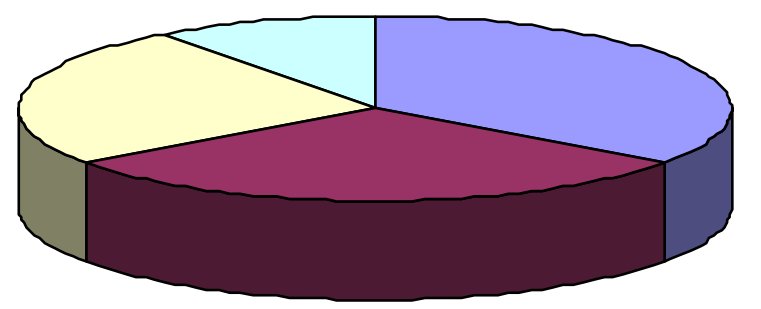

$\square$ Electronic and photocopier

components, 35\%

Glass manufacturing, 30\%

$\square$ Chemical and pigments, 25\%

$\square$ Other, $10 \%$

\section{Figure 1 Selenium production usage in each industry.}

Selenium is most commonly produced from selenide in many sulfide ores, such as those of copper, silver, or lead. It is obtained as a byproduct of the processing of these ores, from the anode mud of copper refineries and the mud from the lead chambers of sulfuric acid plants. These mud can be processed by a number of means to obtain free selenium. There are around 40 known selenium-containing minerals, some of which can have as much as $30 \%$ selenium - but all are rare. The main producing countries are Canada, USA, Bolivia and Russia. Global industrial production of selenium is around 1500 tons a year and about 150 tons of selenium are recycled from industrial waste and reclaimed from old photocopiers (Lenntech, 2007).

Selenium concentration in fresh water is usually around $0.02 \mathrm{mg} / \mathrm{L}$. The selenium content of surface water is greatly influenced by $\mathrm{pH}$, being high in acidic $(\mathrm{pH}<3.0)$ and in alkaline waters $(\mathrm{pH}>7.5)$. Selenium compounds are released to the air during the combustion of coal and petroleum fuels, and during the smelting and refining of other metals. From 1987 to 1993 , according to the Toxics Release Inventory published by EPA 
(2006) selenium releases to land and water totaled over 1 million lbs. These releases were primarily from copper smelting industries. It was also reported that two states of largest releases and largest direct releases to water occurred in Utah and Indiana, respectively according to EPA (2006). Traces of selenium ranging from $0-0.01 \mathrm{mg} / \mathrm{L}$ are commonly found in community drinking water in USA. The MCLG for selenium has been set at $0.05 \mathrm{mg} / \mathrm{L}$ because EPA believes this level of protection would not cause any of the potential health problems.

Recently, selenium levels in soils and waters increase because selenium settles from air and selenium from waste also tends to end up in the soils of disposal sites (Lenntech, 2007). If there is no reaction occurred between selenium in soils and oxygen, selenium will remain immobile. Immobile selenium shows less solubility in water and therefore less risk for organisms. However, the oxygen levels in the soil and the acidity of the soil will increase mobile forms of selenium. Higher oxygen levels and increased acidity of soils is usually caused by human activities, such as industrial and agricultural processes. When selenium is more mobile, the chances of exposure to its compounds will be greatly enhanced. Soil temperatures, moisture, concentrations of water-soluble selenium, the season of the year, organic matter content and microbial activity determine how fast selenium will move through soil. In other words, these factors determine its mobility. Agriculture cannot only increase the selenium content in soil; it can also increase selenium concentrations in surface water, as selenium is brought along in irrigation drainage water. 


\subsection{Toxicity}

The toxicity of selenium depends on whether it is in the biologically active oxidized form (USEPA, 2006). In alkaline soils and oxidizing conditions, selenium may be oxidized sufficiently to maintain the availability of its biologically active form, and cause plant uptake of the metal to be increased. In acidic or neutral soils, it tends to remain relatively insoluble and the amount of biologically available selenium should steadily decrease. Selenium volatilizes from soils when converted to volatile selenium compounds (e.g., dimethyl selenide) by microorganisms (FRTR, 2002). Elemental selenium and most metallic selenides have relatively low toxicities because of their low bioavailability. By contrast, selenate and selenite are very toxic, and have modes of action similar to that of arsenic (Swinden, L., 2007). Hydrogen selenide is an extremely toxic, corrosive gas. Selenium also occurs in organic compounds such as dimethyl selenide, selenomethionine and selenocysteine, all of which have high bioavailability and are toxic in large doses. Selenium dioxide is the primary source of problems from industrial exposures since the dioxide forms selenious acid with water or sweat, and the acid is an irritant. Selenium compounds released during coal or petroleum combustion may be a significant source of exposure.

\subsubsection{Acute Symptom}

Selenium is an essential nutrient at low levels. However, once the exposure concentration of selenium above the MCL suggested by EPA, it might cause several acute symptoms such as hair and fingernail changes, damage to the peripheral nervous system, fatigue and irritability (USEPA, 2006).

\subsubsection{Chronic Symptom}


Selenium has the potential to cause the following health effects from long-term exposures at levels above the MCL: hair and fingernail loss; damage to kidney and liver tissue, and the nervous and circulatory systems (USEPA, 2006).

\subsection{Selenium Reactions}

Though selenium is one of the trace elements on the earth, it is rather complex to understand its general behavior. Several parameters (i.e. $\mathrm{pH}$, redox potential, microbial cativity and presence of complexing and precipitation agents) could affect its predominant species, motility and toxicity (Séby, et al., 1998). To identify the properties for each species, we need to review its reactions in different conditions.

\subsubsection{Selenium Oxidation-Reduction Reactions}

Selenium exists on the earth in several valences status, oxidation - reduction reactions are important processes that can affect both the chemical speciation and the stability of selenium in natural environment; these reactions are strongly influenced by the potential and $\mathrm{pH}$ (Séby, et al., 1998). In aqueous medium, a potential-pH diagram as Figure 2 for a selenium activity of $10^{-7} \mathrm{~mol} / \mathrm{L}$ can provide information on the chemical stability and the redox chemistry of this element as a function of these parameters. 
Table 1. Standard thermodynamic data used to establish the potential-pH diagram (Séby, et al., 1998).

\begin{tabular}{|c|c|}
\hline Redox reactions & Standard potential (V) \\
\hline \multicolumn{2}{|l|}{$\mathrm{Se}(0) / \mathrm{Se}(-\mathrm{II})$} \\
\hline $\mathrm{Se}(s)+2 H^{+}+2 e^{-} \Leftrightarrow \mathrm{H}_{2} \mathrm{Se}(a q)$ & -0.115 \\
\hline $\mathrm{Se}(s)+H^{+}+2 e^{-} \Leftrightarrow H S e^{-}$ & -0.227 \\
\hline $\mathrm{Se}(s)+2 e^{-} \Leftrightarrow S e^{-}$ & -0.641 \\
\hline \multicolumn{2}{|l|}{$\mathrm{Se}(\mathrm{IV}) / \mathrm{Se}(0)$} \\
\hline $\mathrm{H}_{2} \mathrm{SeO}_{3}(a q)+4 \mathrm{H}^{+}+4 e^{-} \Leftrightarrow \mathrm{Se}(s)+3 \mathrm{H}_{2} \mathrm{O}$ & 0.740 \\
\hline $\mathrm{H}_{2} \mathrm{SeO}_{3}+5 \mathrm{H}^{+}+4 e^{-} \Leftrightarrow \mathrm{Se}(s)+3 \mathrm{H}_{2} \mathrm{O}$ & 0.780 \\
\hline $\mathrm{SeO}_{3}^{2}+6 \mathrm{H}^{+}+4 e^{-} \Leftrightarrow \mathrm{Se}(s)+3 \mathrm{H}_{2} \mathrm{O}$ & 0.903 \\
\hline \multicolumn{2}{|l|}{$\mathrm{Se}(\mathrm{VI}) / \mathrm{Se}(\mathrm{IV})$} \\
\hline $\mathrm{HSeO}_{4}^{-}+3 \mathrm{H}^{+}+2 e^{-} \Leftrightarrow \mathrm{H}_{2} \mathrm{SeO}_{3}(a q)+\mathrm{H}_{2} \mathrm{O}$ & 1.090 \\
\hline $\mathrm{HSeO}_{4}^{-}+2 \mathrm{H}^{+}+2 e^{-} \Leftrightarrow \mathrm{HSeO}_{3}^{-}+\mathrm{H}_{2} \mathrm{O}$ & 1.008 \\
\hline $\mathrm{HSeO}_{4}^{-}+\mathrm{H}^{+}+2 e^{-} \Leftrightarrow \mathrm{SeO}_{3}^{2-}+\mathrm{H}_{2} \mathrm{O}$ & 0.760 \\
\hline $\mathrm{SeO}_{4}^{2-}+4 \mathrm{H}^{+}+2 e^{-} \Leftrightarrow \mathrm{H}_{2} \mathrm{SeO}_{3}(a q)+\mathrm{H}_{2} \mathrm{O}$ & 1.139 \\
\hline $\mathrm{SeO}_{4}^{2-}+3 \mathrm{H}^{+}+2 e^{-} \Leftrightarrow \mathrm{HSeO}_{3}^{-}+\mathrm{H}_{2} \mathrm{O}$ & 1.060 \\
\hline $\mathrm{SeO}_{4}^{2-}+2 \mathrm{H}^{+}+2 e^{-} \Leftrightarrow \mathrm{SeO}_{3}^{2-}+\mathrm{H}_{2} \mathrm{O}$ & 0.811 \\
\hline Acid-Base reactions & $p K_{a}$ \\
\hline \multicolumn{2}{|l|}{ Se (-II) } \\
\hline $\mathrm{H}_{2} \mathrm{Se}+\mathrm{H}_{2} \mathrm{O} \Leftrightarrow \mathrm{HSe}^{-}+\mathrm{H}_{3} \mathrm{O}^{+}$ & 3.8 \\
\hline $\mathrm{HSe}^{-}+\mathrm{H}_{2} \mathrm{O} \Leftrightarrow \mathrm{Se}^{2-}+\mathrm{H}_{3} \mathrm{O}^{+}$ & 14 \\
\hline \multicolumn{2}{|l|}{ Se (IV) } \\
\hline $\mathrm{H}_{2} \mathrm{SeO}_{3}+\mathrm{H}_{2} \mathrm{O} \Leftrightarrow \mathrm{HSeO}_{3}^{-}+\mathrm{H}_{3} \mathrm{O}^{+}$ & 2.68 \\
\hline $\mathrm{HSeO}_{3}^{-}+\mathrm{H}_{2} \mathrm{O} \Leftrightarrow \mathrm{SeO}_{3}^{2-}+\mathrm{H}_{3} \mathrm{O}^{+}$ & 8.4 \\
\hline \multicolumn{2}{|l|}{ Se (VI) } \\
\hline $\mathrm{H}_{2} \mathrm{SeO}_{4}+\mathrm{H}_{2} \mathrm{O} \Leftrightarrow \mathrm{HSeO}_{4}^{-}+\mathrm{H}_{3} \mathrm{O}^{+}$ & -2.01 \\
\hline $\mathrm{HSeO}_{4}^{-}+\mathrm{H}_{2} \mathrm{O} \Leftrightarrow \mathrm{SeO}_{4}^{2-}+\mathrm{H}_{3} \mathrm{O}^{+}$ & 1.73 \\
\hline
\end{tabular}

At high redox potential values, Se (VI) is predominant in a wide $\mathrm{pH}$ range under the $\mathrm{SeO}_{4}{ }^{2-}$ form. In the moderate potential values, Se (IV) is stable and according to the $\mathrm{pH}$, can be present as $\mathrm{H}_{2} \mathrm{SeO}_{3}, \mathrm{HSeO}_{3}{ }^{-}$or $\mathrm{SeO}_{3}{ }^{2-}$. In reducing environment, elemental 
selenium can exist in a wide $\mathrm{pH}$ range. Under more reducing conditions, Se (-II) is predominant with $\mathrm{HSe}^{-}$as major Se species in solution. However, these observations based on thermodynamic considerations are often misleading when applied to natural waters particularly at trace levels (Abdullab, 1995). An accurate interpretation of the selenium behavior requires in situ speciation determinations (Devereln et al., 1994; Séby et al. 1997; Fio and Fujii, 1990). 


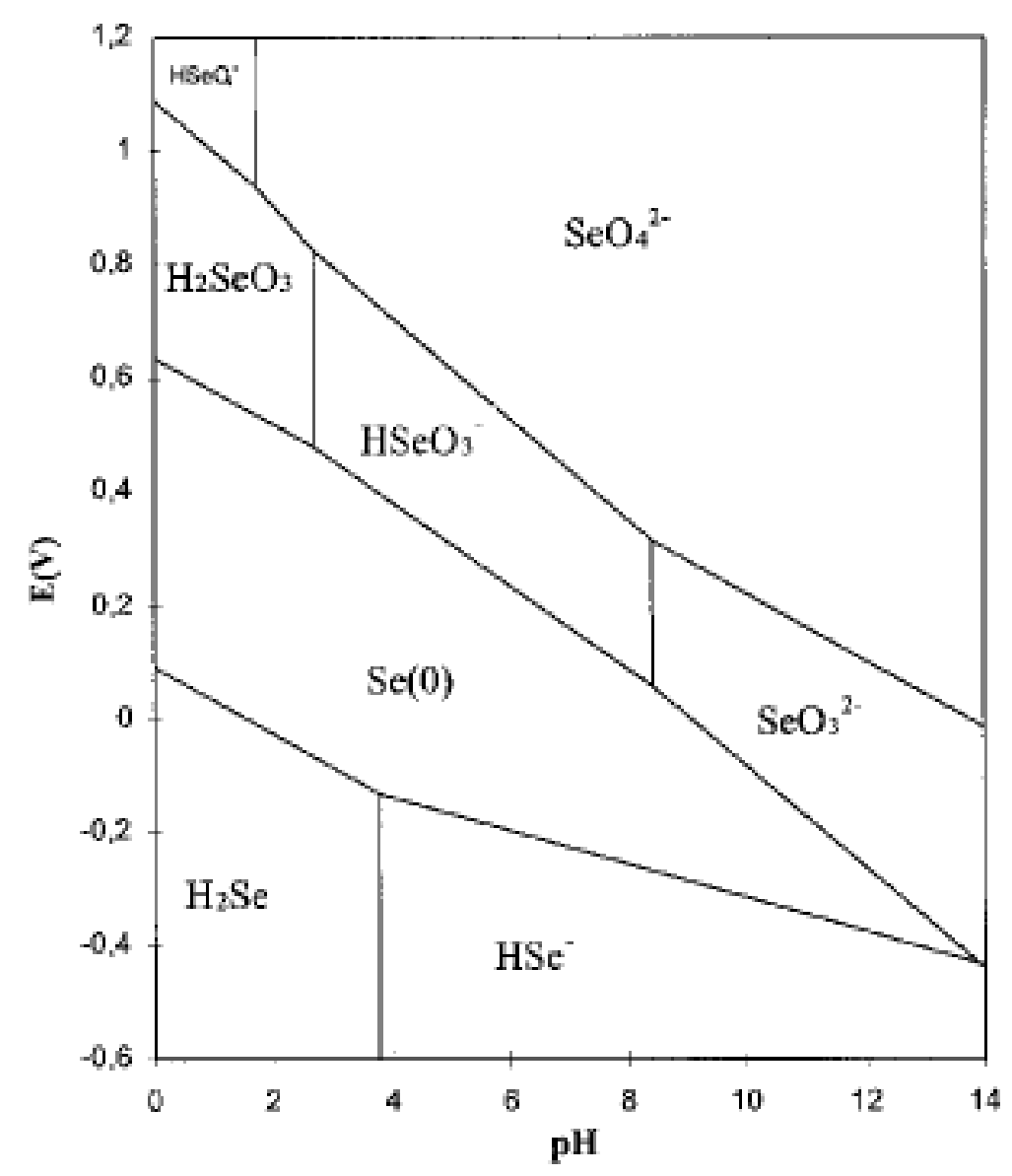

Figure 2. Selenium potential-pH diagram at $25^{\circ} \mathrm{C}$ for a dissolved selenium activity of $10^{-7} \mathrm{~mol} / \mathrm{L}$ (Séby, et al., 1998).

\subsubsection{Se Sorption/Desorption Reactions}

In oxidized to moderately reduced environment, the selenium distribution between solid and aqueous phases depends mainly on sorption/desorption reactions, particularly at trace levels (Neal et al., 1987a). These reactions can occur on different solid surfaces such as inorganic solids and organic matter (Öhman, 1988).

\subsubsection{Sorption Reactions on Inorganic Materials}

On the surfaces of inorganic materials (i.e. minerals, soils, iron oxides, alumina, etc.), 
selenium adsorption behavior depends on its oxidation state: selenate sorption is generally much lower than selenite sorption (Ahlrichs and Hossner, 1987; Balistrieri and Chao, 1987; Saeki et al., 1995). For Se (IV), different studies have shown a strong affinity to materials that rich in metallic oxides or/and hydroxides (iron, manganese, aluminium, etc). The sorption mechanism of Se (IV) was broadly studied and involve very often a ligand exchange reaction with formation of an inner-sphere surface complex (Monteil-Rivera et al., 2000; Namasivayam and Prathap, 2006). Previous studies also indicated that the selenite adsorption was significantly $\mathrm{pH}$ dependent. It showed a lower affinity when it was sorbed by $\mathrm{Al}$ and Fe oxides or clays (Parida et al, 1997). The mechanism for the sorption was commonly accepted as surface complexation involving the $\mathrm{SeO}_{3}{ }^{2-}$ and $\mathrm{HSeO}_{3}{ }^{-}$sorbed onto the surface sites by ligand exchange (Monteil-Rivera et al, 2000).

The adsorbed Se (IV) amounts as a function of time show a two steps behavior: the first part of the curve indicate a fast and linear retention which becomes slower with time (Balistrieri and Chao, 1987; Papelis et al., 1995; Papelis et al., 1995; Del Debbio, 1997). Two general kinetic models had been applied to the selenite adsorption: (1) firstorder kinetic model and (2) pseudo-second-order kinetic model. The two models can be described by equations (1) and (2), respectively:

$$
\begin{aligned}
& \log \left(q_{e}-q\right)=\log q_{e}-\frac{k_{1} t}{2.303} \\
& \frac{t}{q}=\frac{1}{k_{2} q_{e}^{2}}+\frac{t}{q_{e}}
\end{aligned}
$$


where, $q_{e}$ and $q$ (mg-Se/g-adsorbent) are the amount of selenium (III) adsorbed at equilibrium and at time $t$, respectively; $t$ ( $\min )$ is the adsorption time. $k_{1}$ and $k_{2}$ represent the rate constants for first and second order reactions.

Previous studies indicated that selenite adsorption kinetics could be characterized better by the pseudo-second-order kinetic model (Kuan, et al., 1998; Namasivayam and Prathap, 2006). Goh and Lim (2004) reported that selenite adsorption can be described by Elovich rate law, the rate of selenite adsorption decreased exponentially with the increasing selenium coverage on the surface of adsorbents when tropical soils were utilized to remove selenium. The linear form of the Elovich equation can be expressed as:

$$
q=\frac{1}{\alpha} \ln (a \alpha)+\frac{1}{\alpha} \ln \left(t+\frac{1}{a \alpha}\right)
$$

where, $a$ and $\alpha$ are Elovich kinetic constants. In other works, it was assumed that adsorption rate is controlled by an intraparticulate mass transfer in the solid (Papelis et al, 1995; Papelis et al, 1995).

For adsorption equilibrium, the Langmuir model and the Freundlich model were widely used. The Langmuir model is used to reveal the equilibrium between surface and solution as a reversible chemical equilibrium between species. It suggests a monolayer sorption, with no lateral interaction between the adsorbed molecules. Equation for Langmuir model can be expressed as follow (Crittenden et al., 2005):

$$
q_{e}=\frac{q_{\max } C_{e}}{b+C_{e}}
$$

where $C_{e}(\mathrm{mg} / \mathrm{L})$, the equilibrium concentration in the solution; $q_{\max }$ (mg-Se/g-adsorbent), represents the maximum adsorption capacity; adsorption constant $b(\mathrm{~L} / \mathrm{mg})$, is related to 
the energy of adsorption, it is both temperature-dependent and related to the Gibbs free energy and hence to the enthalpy change for the adsorption process.

Freundlich model originally proposed as an empirical equation is used to describe the data for heterogeneous adsorbents such as activated carbon. The model can be expressed as follow (Crittenden et al., 2005):

$$
q_{e}=K_{f} C_{e}^{1 / n}
$$

Where $K_{f}$ and $1 / n$ are parameters of the Freundlich isotherm. $K_{f}(m g / g)(L / m g)^{\frac{1}{n}}$, reveals the adsorption capacity and $1 / n$ unitless, the intensity of adsorption.

Kuan et al. (1998) reported that when applied the aluminum-oxide coated sand to the selenite adsorption, the adsorption capacity could reach $1.08 \mathrm{mg}$-Se (IV)/g-adsorbent with the coefficient of linear regression $\left(R^{2}\right)$ for Langmuir model calculated to be 0.98 at pH 4.6. Lo and Chen (1997) obtained the adsorption capacity value of $0.017 \mathrm{mmol}-\mathrm{Se}$ (IV)/g-adsorbent at $\mathrm{pH} 4.0$, as iron-coated sand was used.

The weaker sorption of Se (VI) compared to Se (IV) was observed on different solid surfaces (Masscheleyn and Patrick, 1993; White and Dubrovsky, 1994; Balishtrieri, 1987) and could be explain by the formation of an outersphere complex at the solid surface (Saeki et al., 1995; Davis and Leckie, 1980). Adsorption of Se (VI) is also strongly affected by the $\mathrm{pH}$ with a similar behavior to Se (IV) (Ahlrichs and Hossner, 1987; Saeki et al., 1995; Vuori et al., 1994).

\subsubsection{Sorption Reactions on Organic Matter}

Interactions between selenium and organic matter such as humic substances were reported for Se (IV) (Gustafsson and Johnsson, 1994). From iron oxyhydroxide coated 
with sodium humate, it was observed a more important immobilization of Se (IV) compared to the mineral alone. In order to clarify the association between selenite and humic substances, some authors have assigned the retention of $\mathrm{Se}(\mathrm{IV})$ to a microbial reductive incorporation on soils and aquatic systems and this reaction would occur mainly in the low molecular-weight-fraction of the humic substances (fulvic acids) (Gustafsson and Johnsson, 1994). The mechanism of selenite sorption on organic matter is not yet well understood and incorporation or adsorption reactions could occur alone or in a simultaneous way.

\subsubsection{Selenium Complexation Reactions}

In aqueous phase, selenium can exist in the form of complexes mainly as ion pairs that are in association with inorganic cations (White and Dubrovsky, 1994; Elrashidi et al, 1987; Reddy et al., 1995). A number of works has experimentally shown the presence of these Se compounds. Only a study on Se speciation in groundwater samples has shown the occurrence of $\mathrm{MgSeO}_{4(\mathrm{aq})}$ by using the specific adsorption properties of the divalent $\mathrm{Se}(\mathrm{IV})$ and $\mathrm{Se}(\mathrm{VI})$ species on CuO solid particles (Reddy et al., 1995).

Equilibrium thermodynamic calculations for a groundwater at $\mathrm{pH}=7$ containing a total selenium concentration of $300 \mathrm{mg} / \mathrm{L}$ have shown that under oxidizing conditions $(E$ $>400 \mathrm{mV}), \mathrm{SeO}_{4}{ }^{2-}$ and $\mathrm{CaSeO}_{4(\mathrm{aq})}$ are the predominant species in aqueous solution. For potentials ranging from 0 to $400 \mathrm{mV}$, the most stable species are $\mathrm{CaSeO}_{3(\mathrm{aq})}$ and $\mathrm{SeO}_{3}{ }^{2-}$ and, under more reducing conditions $(E<0 \mathrm{mV})$, only $\mathrm{HSe}^{-}$is present in solution (White and Dubrovsky, 1994). A similar study was carried out in soil solutions and none of the 27 complexes studied were found to contribute significantly to the total soluble selenium 
concentration. Only the $\mathrm{SeO}_{4}{ }^{2-}, \mathrm{HSeO}_{3}^{-}, \mathrm{SeO}_{3}{ }^{2-}, \mathrm{H}_{2} \mathrm{Se}$ and $\mathrm{HSe}^{-}$dissolved forms

predominate according to the $\mathrm{pH}$ and potential conditions (Elrashidi et al, 1987).

\subsection{Selenium Treatment Technologies}

Since selenium first drove significant public concern in early 80 s because of its bioaccumulation in birds at California's Kesterson Reservoir in the San Joaquin Valley (SJV), several treatment technologies were developed for selenium removal from agriculture drainage and industrial waste water to date. These conventional treatment technologies include physical, chemical and biological methods. Although much has been learned, the goal of finding practical, cost-effective technology for treating selenium contaminated water has not yet been accomplished (Losi and Frankenberger Jr., 1997). An integrated, multiphased approach to the problem will most likely prove necessary and feasible.

\subsubsection{Ion exchange}

Ion exchange involves the exchange of an undesirable dissolved constituent for a more desirable solute electrostatically attached to an ion exchange material (Frankenberger Jr. et al., 2004). Ion exchange is a very simple process to operate and is suitable for intermittent flow. Resin for the ion exchange process is often synthetic. Research indicates that resins work effective for removing arsenic, selenium and other ionic constituents. However, it is reported that ion exchange is more effective in removing selenite rather than selenate (Mavrov et al, 2006), which is due to the similar structure and chemical properties between selenate and sulfate. As the fact of that, it is difficult to separate selenate from sulfate since a resin would quickly become saturated 
with sulfate ions and stop removing selenate. The cost for ion exchange is less than that for reverse osmosis. But the high chemical regeneration cost for the resin make this technology unattractive, especially for the waste water with the higher total dissolved solids (i.e. a few hundred $\mathrm{mg} / \mathrm{L}$ ).

\subsubsection{Chemical reduction with Zero-Valent Iron}

Iron filings (zero-valent iron) can be used to remove selenium from water. Iron acts as both a catalyst and reductant (electron donor) for the reaction. Selenium is reduced to selenite, elemental selenium, and selenide depending upon $\mathrm{pH}$ and $\mathrm{O}_{2}$ dissolved in water. The more reduced forms of selenium have an affinity to lower $\mathrm{pH}$ and less oxygen containing. Along with the reduced selenium formation, iron will be oxidized to form precipitates. The iron precipitates has not been identified yet, but recent

work suggests that "green-rust" $\left(\mathrm{Fe}_{4}^{\mathrm{II}} \mathrm{Fe}^{\mathrm{III}}{ }_{2}(\mathrm{OH})_{12} \mathrm{SO}_{4} \cdot \mathrm{nH}_{2} \mathrm{O}\right)$ may be the initial precipitate, which can then be oxidized to magnetite $\left(\mathrm{Fe}_{3} \mathrm{O}_{4}\right)$ by nitrate and oxygen (Hansen et al. 1996). Other likely precipitates include siderite $\left(\mathrm{FeCO}_{3}\right)$ and ferrihydrite $\left[\mathrm{Fe}(\mathrm{OH})_{3}\right]$. The advantage of zero-valent iron is that it can reduce the concentration of selenium to very low degree and might be useful as a polishing step following microbial treatments. If the wastewater is anaerobic as a result of the microbial treatment, the formation of secondary $\mathrm{Fe}$ (III) precipitates is minimized.

\subsubsection{Catalyzed Cementation of Selenium}

Catalyzed cementation is a process that was developed to remove arsenic and other heavy metals such as thallium and selenium from water (MSE Technology Applications, Inc., 2001). The term catalyzed cementation describes the process's ability to remove heavy metals from solution by cementation on the surface of the iron particles. 
It was anticipated that the catalyzed cementation process would have the ability to treat and remove selenium from solution regardless of its valence state $(+6$ or +4$)$. To optimize the cementation process, proprietary catalysts are added to the process to increase the selenium removal efficiency.

\subsubsection{Biological Treatment}

Selenate and selenite can be reduced readily in most systems through interactions with organic matter or via microbiological processes that drive elemental selenium formation to stabilize it and remove the toxicity by providing reducing conditions and overcoming kinetic barriers to selenium reduction (Kenward et al., 2006). Many studies have shown that Se-reducing bacteria can effectively catalyze the reduction of selenate into elemental selenium. Other strains of bacteria may further reduce elemental selenium to selenide or oxidize selenide to form elemental selenium (Doran et al., 1977). Most of these microbe-mediated processes actively reduce selenate to elemental selenium by utilizing selenate as a terminal electron acceptor during the respiration of organic carbon. For example, in agricultural drainage water of the San Joaquin Valley, CA, selenate was effectively reduced to elemental selenium by Enterobacter taylorae (Zhang et al., 2003) using this pathway.

Biological treatment technology has been applied in industry (MSE Technology Applications, Inc., 2001). Applied Biosciences Corporation developed the BSeR ${ }^{\mathrm{TM}}$ process using BASBR. Selenium (selenate and selenite) was reduced to elemental selenium by specially developed biofilms containing specific proprietary microorganisms. This process produces a precipitate of elemental selenium. With the aid of backflushing, $97 \%$ of the selenium reduced in the system can be removed from the bioreactors. 


\subsubsection{Ferrihydrite Adsorption of Selenium}

Ferrihydrite precipitation with concurrent adsorption of selenium onto the ferrihydrite surface (ferrihydrite adsorption) is EPA's BDAT for treating seleniumbearing waters (MSE Technology Applications, Inc., 2001). For adsorption of selenium using ferrihydrite to occur, the ferric ion $\left(\mathrm{Fe}^{+3}\right)$ must be present in the water. Selenate $\left(\mathrm{Se}^{+6}\right)$ is most effectively removed from the water at $\mathrm{pH}$ levels below 4 . The chemical reactions for ferrihydrite precipitation of selenium are:

$$
\begin{aligned}
& \mathrm{Fe}^{3+}+3 \mathrm{H}_{2} \mathrm{O} \rightarrow \mathrm{Fe}(\mathrm{OH})_{3(\text { solid })}+3 \mathrm{H}^{+} \\
& \mathrm{SeO}_{4}^{2-}+\mathrm{Fe}(\mathrm{OH})_{3(\text { solid })}+4 \mathrm{H}_{2} \mathrm{O} \rightarrow \mathrm{Fe}(\mathrm{OH})_{3(\text { solid })}+\mathrm{SeO}_{4}^{2-}(\text { ad }) \\
& +8 \mathrm{H}^{+}
\end{aligned}
$$

The selenium-iron solid product must be separated from the treated water before the process of selenium removal is complete. During the demonstration, solid-liquid separation was accomplished using a settler and filter press.

\subsection{Background and Application of Activated Carbon}

Activated carbon is widely used in water treatment industries. Traditionally, active carbons are made in particular form as powders or fine granules which are less than $1.0 \mathrm{~mm}$ in size known as powered activated carbon (PAC). Granulated activated carbon (GAC) has a relatively larger particle size compared to PAC and consequently, presents a smaller external surface. Because of the relatively big particle size, GAC could be easily packed into column and applicable for large scale treatment.

\subsubsection{Surface Structures of Activated Carbon}

The structures of activated carbon are important for understanding the mechanism of adsorption reaction between ionic adsorbates and the activated carbon. Activated 
carbons can be prepared from a variety of raw materials such as coal, charcoal, and saw dust. During the activation process, partial oxidation takes place and a pore structure develops (Corapcioglu and Huang, 1987). As a result of oxidation process, many surface functional groups are formed. Carboxyl, phenolic hydroxyl, carbonyl (quinine type), carboxylic acid, anhydrides, lactones and cyclic peroxide are suggested to be the major functional groups associated with the surface pores (Garten, et al., 1957). Ishizaki and Marti (1981) studied the surface oxides of Filtrasorb 200 by direct transmission IR (DTIR) spectrophotometry and suggested that the main surface oxides are lactones, quinones phenols and carboxylates. Quantitative analysis was also reported by Corapcioglu and Huang (1987). Surface property parameters including $\mathrm{pH}_{\mathrm{zpc}}$, total surface sites and intrinsic rate constants, were presented for more than ten types of commercial activated carbons. Reed and Matsumoto (1991) did the similar studies on the surface properties for powered activated carbon.

\subsubsection{Application of Activated Carbon}

Carbon absorption has numerous applications in removing pollutants from air or water streams both in the field and in industrial processes such as:

- Spill cleanup

- Groundwater remediation

- Drinking water filtration

- Air purification

- Volatile organic compounds capture from painting, dry cleaning, gasoline dispensing operations, and other processes

2.5.3 Granular Activated Carbon Used in Adsorption Removal of Heavy Metal Pollutants 
Different kinds of modified activated carbon were investigated for removing various heavy metals from aqueous solutions. Hoskins et al. (2002) used silver impregnated GAC to remove and sequester iodide from water. Precipitation and adsorption were found to be two dominant removal mechanisms. Adsorption capacity of $450 \mu \mathrm{mole} / \mathrm{g}$ was observed at $\mathrm{pH}$ 5. Effective fine-grained activated carbon which was functionalized with amine was developed by Yantasee et al. (2004) to remove copper (II) from aqueous waste. The saturation capacity was reported to be $0.86 \mathrm{mmol} \mathrm{Cu} / \mathrm{g}$. The Langmuir and the Redlich-Peterson isotherm models characterized the adsorption successfully. Yang, et al (2007) modified the GAC with ployaniline to enhance the adsorption of arsenate. It was found that the modified GAC could greatly remove the arsenic at a trace level. The modification of GAC suggested a broad the optimal $\mathrm{pH}$ for arsenate adsorption comparing with virgin GAC. They also studied the fix bed adsorption for arsenate. A fix-bed model was applied to describe the adsorption behavior. Jang, et al. (2008) incorporated hydrous ferric oxide (HFO) into GAC via incipient wetness impregnation and investigated capabilities of the adsorbents in arsenic removal. Different temperatures were studied for curing the iron impregnation GAC. Results revealed that best temperature for loading iron into mesopore of GAC was $60^{\circ} \mathrm{C}$. Column tests were conducted as well. Arsenic sorption capacity was presented to be 26 mg-As/g when the influent concentration was $300 \mu \mathrm{g} / \mathrm{L}$ 


\section{CHARPTER 3: MATERIALS AND METHODS}

\subsection{Materials}

All the chemical solutions used in this study were analytical grade chemicals and prepared using de-ionized water. Sodium selenite $\left(\mathrm{Na}_{2} \mathrm{SeO}_{3}\right)$ was purchased from MP Biomedicals (Solon, $\mathrm{OH})$. Ferrous chloride $\left(\mathrm{FeCl}_{2} \cdot 4 \mathrm{H}_{2} \mathrm{O}\right)$ and cyclohexane (spectrophotemetric, 99+\%) were purchased from Fisher Scientific, Inc. (Rochester, NY). Sodium hypochlorite (NaClO, 13\%), 2, 3-Diaminonaphthalene (97\%) and hxdroxylamine hydrochloride reagents were obtained from ACROS Organics (Geel, Belgium). Five different types of GACs (Darco $12 \times 20$, Norit GAC 1240, Norit GAC 830, OLC $12 \times 40$ and Filtrasorb 200), provided by Norit Americas Inc. (Marshall, TX) and Calgon Carbon Corp. (Pittsburgh, PA), were used to prepare iron-coated adsorbents.

A $1000 \mathrm{mg} / \mathrm{L}$ selenium (IV) stock solution in the form of selenite was prepared by dissolving $\mathrm{Na}_{2} \mathrm{SeO}_{3}$ into $250 \mathrm{~mL}$ de-ionized water containing $2.5 \mathrm{~mL}$ concentrated hydrochloride acid. A working solution of $4 \mathrm{mg}-\mathrm{Se} / \mathrm{L}$ was prepared using the stock solution for the adsorption experiments.

\subsection{Adsorbent Preparation and Characterizations}

A series of ferrous chloride concentration ranging from $0.005 \mathrm{M}$ to $0.2 \mathrm{M}$ were used for GAC coating to examine the effect of iron concentration on selenite removal. Each solution was prepared by dissolving $\mathrm{FeCl}_{2} \cdot 4 \mathrm{H}_{2} \mathrm{O}$ into de-ionized water, while nitrogen gas was diffused into the solution to eliminate oxygen from the solution. A predetermined amount of GAC was then added to the solution and $\mathrm{pH}$ of the solution was 
adjusted to $4.3 \pm 0.1$. The mixture was gently stirred while a predetermined volume of $13 \% \mathrm{NaOCl}$ solution was added drop by drop to oxidize the ferrous iron. The coating process was illustrated by Figure 3. The volume of $\mathrm{NaOCl}$ added was determined to obtain 2:0.5 ( $\left.\mathrm{NaOCl}: \mathrm{FeCl}_{2}\right)$ molar ratio. The iron-coated $\mathrm{GAC}$ was then washed with $200 \mathrm{~mL}$ de-ionized water and dried at $80^{\circ} \mathrm{C}$ for 1 hour.

The iron-coated samples were examined by a scanning electron microscope (SEM, Hitachi S4700) for surface morphology with the working distance of $12 \mathrm{~mm}$ and an accelerating voltage of $20 \mathrm{KeV}$ was applied. The SEM was equipped with an EDS and it was used to perform the analysis of chemical constituents of the adsorbents. BET surface area and mesoporous size distribution were estimated by nitrogen adsorption and desorption analysis (Micrometritics, ASAP 2020).

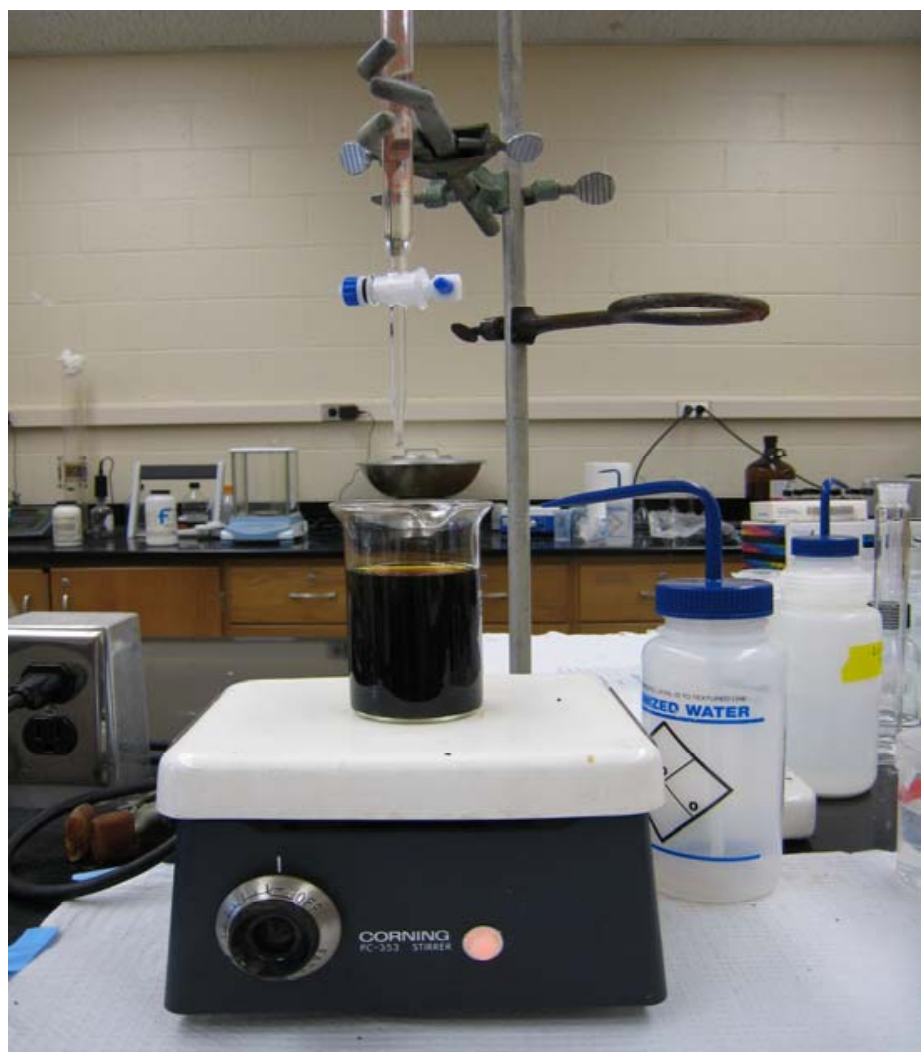

Figure 3. Process of ferrous chloride coated onto GAC surface. 


\subsection{Selenium (III) Measurement}

A colorimetric method was used to measure selenium (III) concentration (USEPA standard methods 3500C, 1998). The method relied on a reaction of selenite ion with DAN that produced a brightly colored and strongly fluorescent piazselenol compound, which was extracted in cyclohexane and measured colorimetrically. The DAN solution was prepared by dissolving $200 \mathrm{mg} \mathrm{DAN}$ in $200 \mathrm{~mL} \mathrm{HCl}(0.1 \mathrm{~N})$, and then extracted three times using $25 \mathrm{~mL}$ cyclohexane, followed by filtration into an opaque container. An HA-EDTA solution prepared by adding $2.25 \mathrm{~g} \mathrm{Na}_{2}$ EDTA and $6.25 \mathrm{~g}$ hydroxylamine hydrochloride $\left(\mathrm{NH}_{2} \mathrm{OHHCl}\right)$ into $250 \mathrm{~mL}$ de-ionized water was used to eliminate negative interference from $\mathrm{Fe}^{2+}$. For the colometric measurements, $2 \mathrm{~mL}$ of the HAEDTA solution was added to a $50 \mathrm{~mL}$ test tube containing $10 \mathrm{~mL}$ water sample. The mixture solution $\mathrm{pH}$ was adjusted to $1.5 \pm 0.3$ using a $0.1 \mathrm{~N} \mathrm{HCl}$ solution. The sample solution was then added with $5 \mathrm{~mL}$ of the DAN solution and put into a covered water bath at $45{ }^{\circ} \mathrm{C}$ for one and half hours to allow color formation. The sample solution was allowed to cool down and added with $2 \mathrm{~mL}$ cyclohexane. The sample test tube was capped securely and shaken vigorously for 5 minutes, followed by 5 -minute without mixing to separate the organic layer from the aqueous solution. The aqueous phase was removed using a disposable pipet attached to a vacuum line. Organic layer was analyzed by a UV/Visible spectrophotometer (Varian, Cary 50) for selenium concentration.

\subsection{Batch Adsorption Experiments}

The iron-coated GACs were tested for selenite removal in batch systems to investigate the effect of $\mathrm{pH}$ and GAC type. A predetermined amount of the adsorbent was 
first added into three $100 \mathrm{~mL}$ glass flasks, followed by adding 50,25 and $12.5 \mathrm{~mL}$ of the selenite working solution to obtain an adsorbent loading rate of $0.8,1.5$, and $3 \mathrm{~g} \mathrm{Fe}-$ $\mathrm{GAC} / \mathrm{L}$. An acetate buffer solution $(0.01 \mathrm{M})$ was used to control the $\mathrm{pH}$ at $5 \pm 0.3$ and ionic strength was controlled by a $0.1 \mathrm{M} \mathrm{NaCl}$ solution. After shaking for 24 hours at $200 \mathrm{rpm}$ and $25^{\circ} \mathrm{C}$, the mixture was filtered through a $0.45 \mu \mathrm{m}$ membrane filter, and selenite concentration in the filtrate was measured using the colorimetric method. For comparison of adsorption capacity, adsorption experiments with all five adsorbents were conducted at $\mathrm{pH} 5$ at $25{ }^{\circ} \mathrm{C}$. In addition, the effect of ferrous iron concentration was studied by using different $\mathrm{FeCl}_{2}$ concentrations $(0.001 \mathrm{M}-0.2 \mathrm{M})$ for the coating process. The effect of $\mathrm{pH}$ on adsorption was studied by determining the selenite removal efficiency at different $\mathrm{pHs}$. Different $\mathrm{pH}$ values (1 to 12 ) were obtained by adding $0.1 \mathrm{~N}$ $\mathrm{HCl}$ or $50 \% \mathrm{NH}_{3} \cdot \mathrm{H}_{2} \mathrm{O}$ solution. 


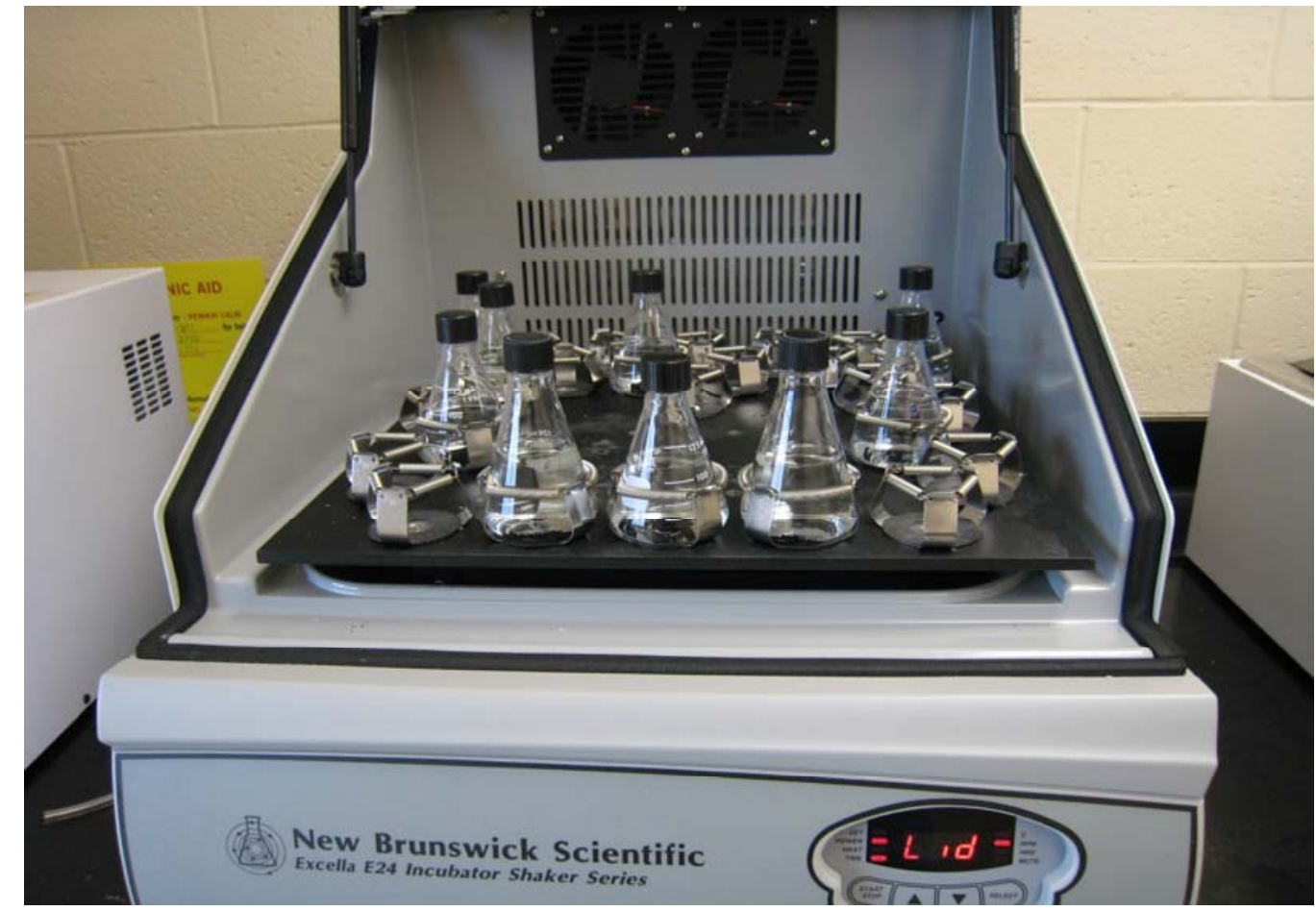

Figure 4. Process of selenite adsorption.

\subsection{Adsorption Kinetics Experiments}

Selenite concentration during the adsorption process was monitored for 48 hours to examine adsorption kinetics. Three initial selenium concentrations $(0.5,1$ and $2 \mathrm{mg} / \mathrm{L})$ with three adsorption loading rates $(0.8,1.5$ and $3 \mathrm{~g} / \mathrm{L})$ were used in the kinetic study. Three temperatures $\left(25,35\right.$ and $\left.45^{\circ} \mathrm{C}\right)$ were applied to determine the temperature effect on the adsorption kinetics.

A second-order model was applied to the kinetic data and a linearized form of the model can be shown as below: 


$$
\frac{t}{q}=\frac{1}{k q_{e}^{2}}+\frac{t}{q_{e}}
$$

where $q_{e}$ and $q$ (mg-Se/g-adsorbent) are the amount of selenium (III) adsorbed at equilibrium and at time $t$, respectively; $t$ (min) is the adsorption time. The values of $k$ and $q_{e}$ were determined using the slope and intercept of linearized model. To characterize the temperature effect, activation energy, $E_{a}$, was calculated using the Arrhenius' equation and a transformed equation is provided as below:

$$
\ln \left(\frac{K_{T_{1}}}{K_{T_{2}}}\right)=\frac{E_{a}}{R}\left(\frac{1}{T_{2}}-\frac{1}{T_{1}}\right)
$$

where $E_{a}(\mathrm{KJ} / \mathrm{mol})$ is the activation energy; $K_{T_{1}}$ and $K_{T_{2}}(\mathrm{~g} /(\mathrm{mg} \cdot \mathrm{min}))$ are the second order adsorption rate constants at temperature $T_{1}$ and $T_{2} ; R\left(8.31 \mathrm{~J} / \mathrm{molK}^{-1}\right)$ is the gas constant; and $T$ is temperature in degree $\mathrm{K}$.

\subsection{Adsorption Isotherm Experiments}

Adsorption isotherms for adsorbent loading of 0.3 to $2.8 \mathrm{~g} / \mathrm{L}$ were developed by letting the reaction last for 48 hours to reach equilibrium according to the kinetic studies. Selenium initial concentrations of $2 \mathrm{mg} / \mathrm{L}$ were used for the isotherm experiments. The $\mathrm{pH}$ of the mixture solutions were fixed at $5 \pm 0.3$ to achieve highest adsorption efficiency based on previous $\mathrm{pH}$ effect studies.

The adsorption isotherms were characterized by the Langmuir and Freundlich models. The Langmuir model is used to characterize the equilibrium between the adsorbent and solution as a reversible chemical equilibrium between the aqueous and solid phases. A linear form of the Langmuir model is given as below: 


$$
\frac{C_{e}}{q_{e}}=\frac{1}{b q_{\max }}+\frac{C_{e}}{q_{\max }}
$$

The Langmuir adsorption constant, $b(\mathrm{~L} / \mathrm{mg})$ and maximum adsorption capacity, $q_{\max }$ (mg-Se/g-adsorbent) can be calculated from the slope and intercept. A dimensionless constant, equilibrium parameter, $R_{L}$, (Parfitt, 1978) was applied to characterize the isotherms:

$$
R_{L}=\frac{1}{1+b C_{0}}
$$

where $b(\mathrm{~L} / \mathrm{mg})$ is the Langmuir constant; and $C_{0}(\mathrm{mg} / \mathrm{L})$ is the initial selenium concentration. The value of $R_{L}$ reveals the type of isotherm and it indicates favorable adsorption when its value is between 0 and 1 (Hall, 1996).

Experiments were carried out at different temperatures $\left(25,35\right.$ and $\left.45{ }^{\circ} \mathrm{C}\right)$ to determine Gibb's free energy $\left(\Delta \mathrm{G}^{0}\right)$. Gibbs free energy $\left(\Delta G^{0}\right)$ for different initial selenium concentrations was calculated by the following equation (Namasivayam and Prathap, 2006):

$$
\Delta G^{0}=-R T \ln (b M)
$$

where, $M$ is the molecular weight of selenite.

Freundlich model originally proposed as an empirical equation was used to describe the data for heterogeneous adsorbents such as activated carbon. A linear form of the Freundlich model is:

$$
\log q_{e}=\log K_{f}+\frac{1}{n} \log C_{e}
$$

Where $k_{f}\left((m g-S e / g-\right.$ adsorbent $\left.)(L / m g)^{\frac{1}{n}}\right)$ reveals the adsorption capacity and $1 / n$ (unitless) is the intensity of adsorption. 


\subsection{Anion Competitive Adsorption}

To test the effects of co-existing anions on selenite adsorptive removal, four types of the oxyanions $\left(\mathrm{SiO}_{3}{ }^{2-}, \mathrm{SO}_{4}{ }^{2-}, \mathrm{PO}_{4}{ }^{3-}\right.$ and $\left.\mathrm{CO}_{3}{ }^{2-}\right)$ of similar molecular structures were evaluated individually. The experiments were conducted at $25^{\circ} \mathrm{C}$ and $\mathrm{pH} 5.0 \pm 0.3$ with the selenium initial concentration of $1 \mathrm{mg} / \mathrm{L}$ and loading rate of $1.5 \mathrm{~g} / \mathrm{L}$. The concentrations of four oxyanions were controlled at three levels $(0.1,1$ and $5 \mathrm{mM})$. 


\section{CHARPTER 4: RESULTS AND DISSCUSION}

\subsection{Best GAC experiment}

The five GAC samples coated with $0.1 \mathrm{M}$ and $0.02 \mathrm{M}$ ferrous chloride were compared for their efficiency of selenite removal after 24 hours of adsorption. Figure 5 shows that Darco $12 \times 20$ GAC was more effective for removing selenite than other GACs. It achieved $95.83 \%$, and $97.09 \%$ removal of selenite when coated with $0.02 \mathrm{M}$ and $0.1 \mathrm{M}$ $\mathrm{FeCl}_{2}$, respectively. Our later research experiments were conducted using the Darco $12 \times 20 \mathrm{GAC}$

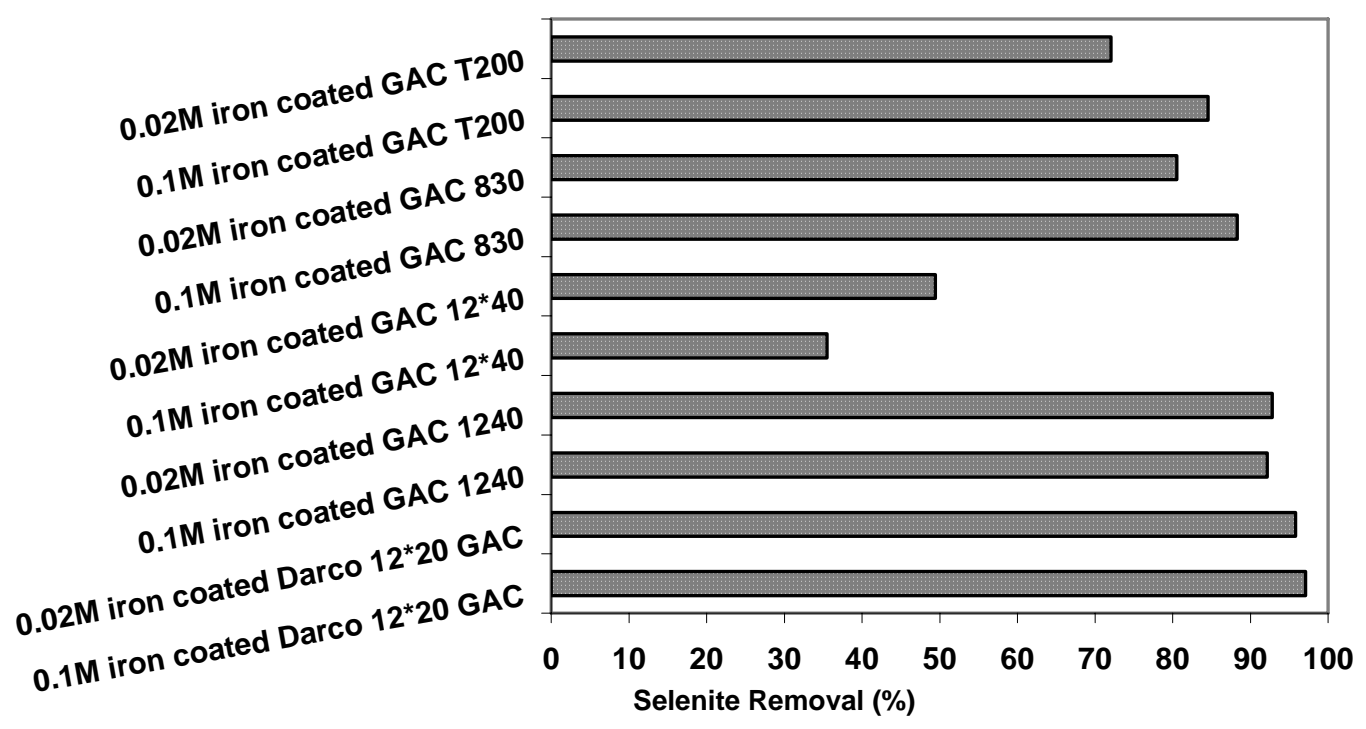

Figure 5. Selenite removal with various types of iron-coated (0.1 $\left.\mathrm{M} \mathrm{FeCl}_{2}\right) \mathrm{GACs}$ 


\subsection{Adsorbent Characterizations}

Table 2 lists the BET specific surface area, total pore volume, and mesopore size of Darco 12x20 GAC and its iron-coated products. The surface area was decreased from $592.6 \mathrm{~m}^{2} / \mathrm{g}$ to $518.6 \mathrm{~m}^{2} / \mathrm{g}$ by the $0.02 \mathrm{M} \mathrm{FeCl}_{2}$ treatment, and further reduced to 434.1

$\mathrm{m}^{2} / \mathrm{g}$ by the $0.1 \mathrm{M} \mathrm{FeCl}_{2}$ treatment. The results were consistent with the data reported in another similar study (Gu et al., 2005). Pore volume and pore size showed a decrease as well. These trends can be attributed to blockage of pores and corresponding surface area by ferric precipitation after the oxidation of ferrous ions by sodium hypochlorite.

Table 2. Surface and pore measurements for Darco 12x20 GAC.

\begin{tabular}{lccc} 
Adsorbent & $\begin{array}{c}\text { BET } \\
\text { surface } \\
\text { area, } \mathbf{m} 2 / \mathbf{g}\end{array}$ & $\begin{array}{c}\text { Pore } \\
\text { Volume, } \\
\mathbf{~ m}^{3} / \mathbf{g}\end{array}$ & $\begin{array}{c}\text { Ave. } \\
\text { Pore } \\
\text { Size, } \mathbf{n m}\end{array}$ \\
\hline Virgin GAC & 592.6 & 0.63 & 4.3 \\
0.02 M Fe-Coated GAC & 518.6 & 0.53 & 4.1 \\
0.1 M Fe-Coated GAC & & & \\
\hline
\end{tabular}


The SEM micrograghs in Figure 6 show that there were considerable small cavities and attached fine particles over the virgin Darco 12x20 surface, forming a system of complicated pore networks. The iron coating on the carbon surface of the treated GAC reduced the number of small cavities. These micrographs clearly show a reduction of pore space and surface area available for adsorption as a result of iron coating. Figure 7 shows the EDS spectra of the adsorbent samples. The intensities of the peaks at $6.38 \mathrm{KeV}$ for iron indicate that higher initial concentration of $\mathrm{FeCl}_{2}$ resulted in a larger amount of iron coating on the GACs. Chlorine also was identified in the coating, which may have originated from $\mathrm{NaOCl}$ or ferrous chloride. The decrease of silicon and aluminum was attributable to their lower energy dispersion signals due to iron coating. 

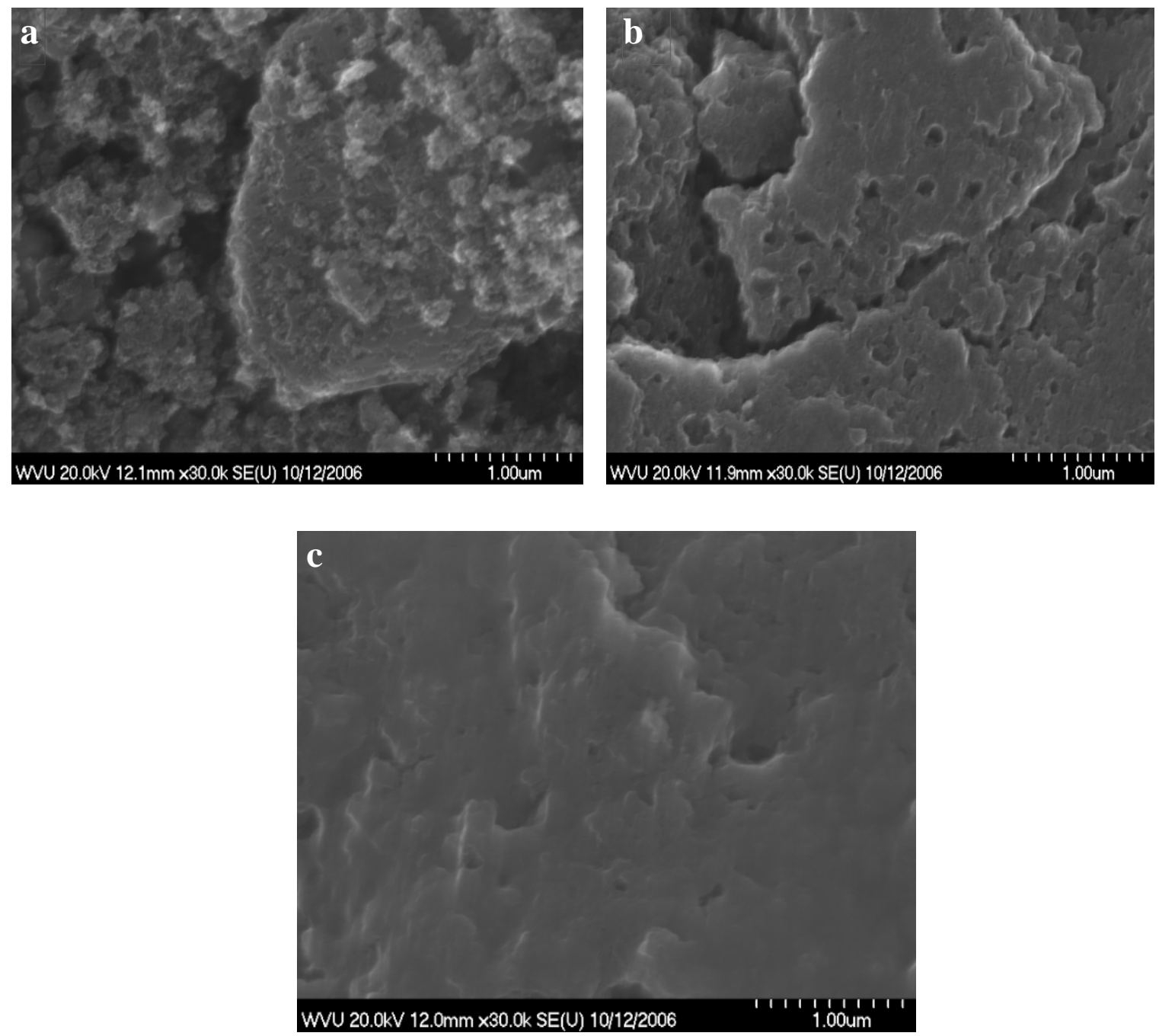

Figure 6. SEM micrographs for iron-coated Darco 12x20 GAC samples: (a) virgin GAC, (b) coated by $0.02 \mathrm{M} \mathrm{FeCl}$ and (c) coated with $0.1 \mathrm{M} \mathrm{FeCl}$. 


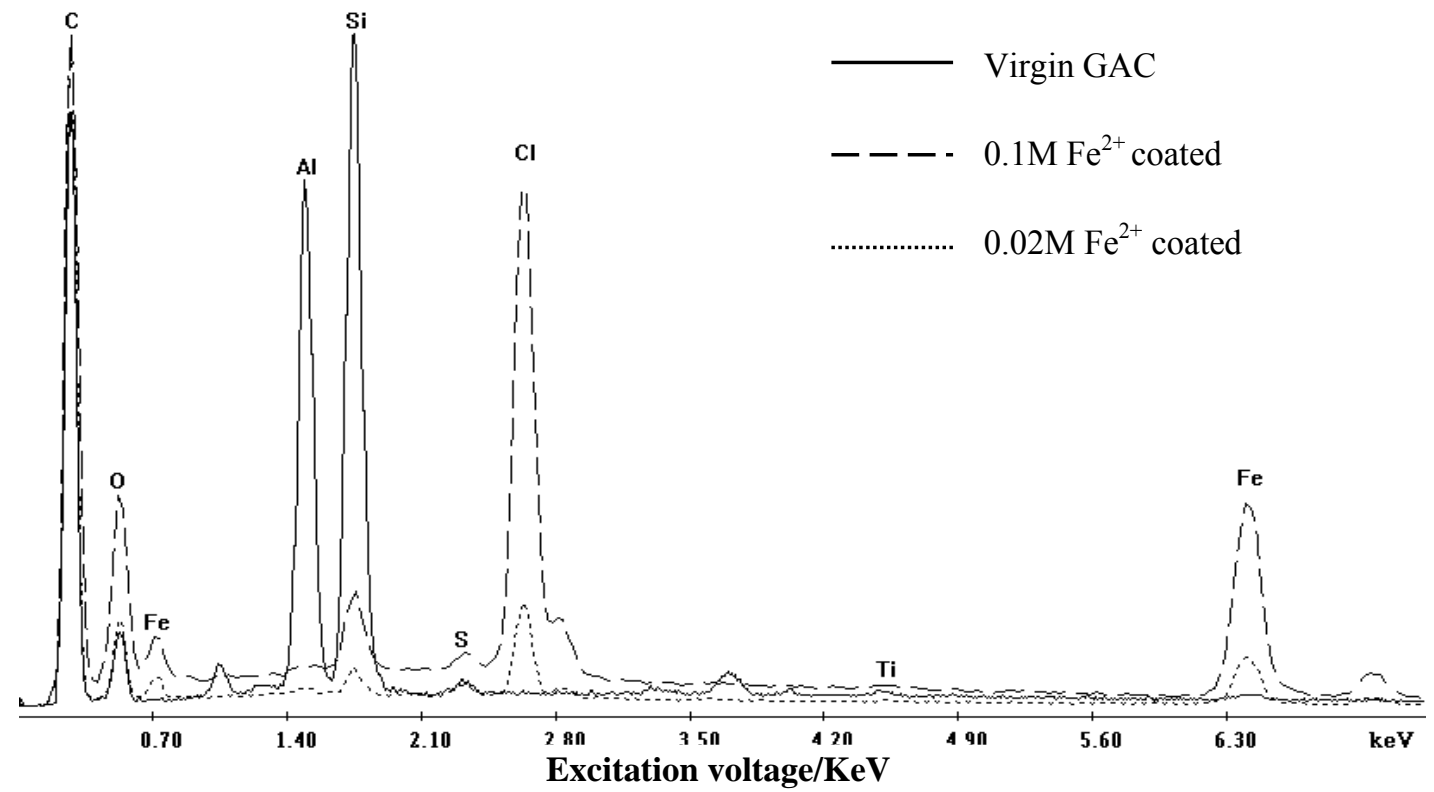

Figure 7. Energy-disperse spectra of the virgin and iron coated Darco 12x20 GAC. 


\subsection{Iron Concentration Effect}

Figure 8 shows that selenite removal efficiency increased with the ferrous chloride concentration used for the iron coating process. The iron coating was found to enhance selenite removal dramatically. The highest efficiency $(97.32 \%)$ was obtained for $0.1 \mathrm{M} \mathrm{FeCl}_{2}$, followed by a slight reduction in the efficiency for $0.2 \mathrm{M}$. The results show a similar trend as that reported by Gu et al. (2005) for arsenate removal. The trend can be explained by two competing factors related to iron coating: (1) higher affinity of iron coating for selenite adsorption which led to increased removal efficiency with $\mathrm{FeCl}_{2}$ concentration, and (2) reduction of the adsorbent surface area due to iron coating such that excessive coating (in this case $0.2 \mathrm{M}$ ) caused a reduction in the removal efficiency.

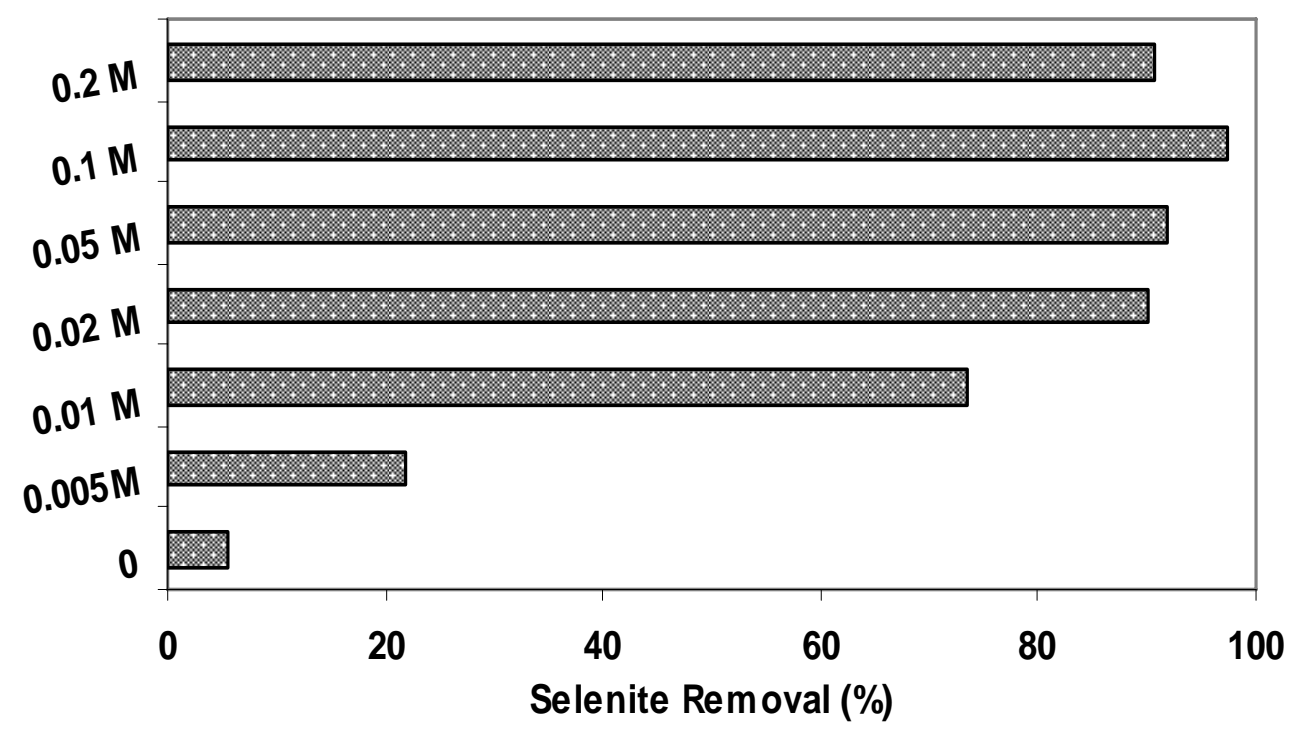

Figure 8. Effect of ferrous chloride concentration used for iron coating on selenite removal using Darco 12x20 GAC. 


\section{4 pH Effect}

The effect of $\mathrm{pH}$ on selenite adsorption was examined with initial selenium concentration of $1 \mathrm{mg} / \mathrm{L}$. Figure 9 shows that the high removal efficiency ( $90 \%$ or above) was not significantly affected by $\mathrm{pH}$ in the range of $2-8$. The removal efficiency decreased as $\mathrm{pH}$ was greater than 8 and reached zero at $\mathrm{pH}$ of 12 . It suggests that the regeneration of the adsorbents can be achieved by increasing the $\mathrm{pH}$. It has been reported that increasing $\mathrm{pH}$ values resulted in a decrease of the adsorption removal of selenite within the $\mathrm{pH}$ range of $2-10$ for other adsorbents such as aluminum-oxide-coated sand and tropical soil (Kuan et al., 1998; Goh and Lim, 2004). As for the study on the polymorphic form of iron oxyhydroxides, there is no apparent decrease observed within the $\mathrm{pH}$ range of $2-7$ (Parida et al., 1997). This fact indicates that when ferric oxide was involved into the adsorbents, it resulted in a wider effective $\mathrm{pH}$ range for removing selenite comparing with other materials. 


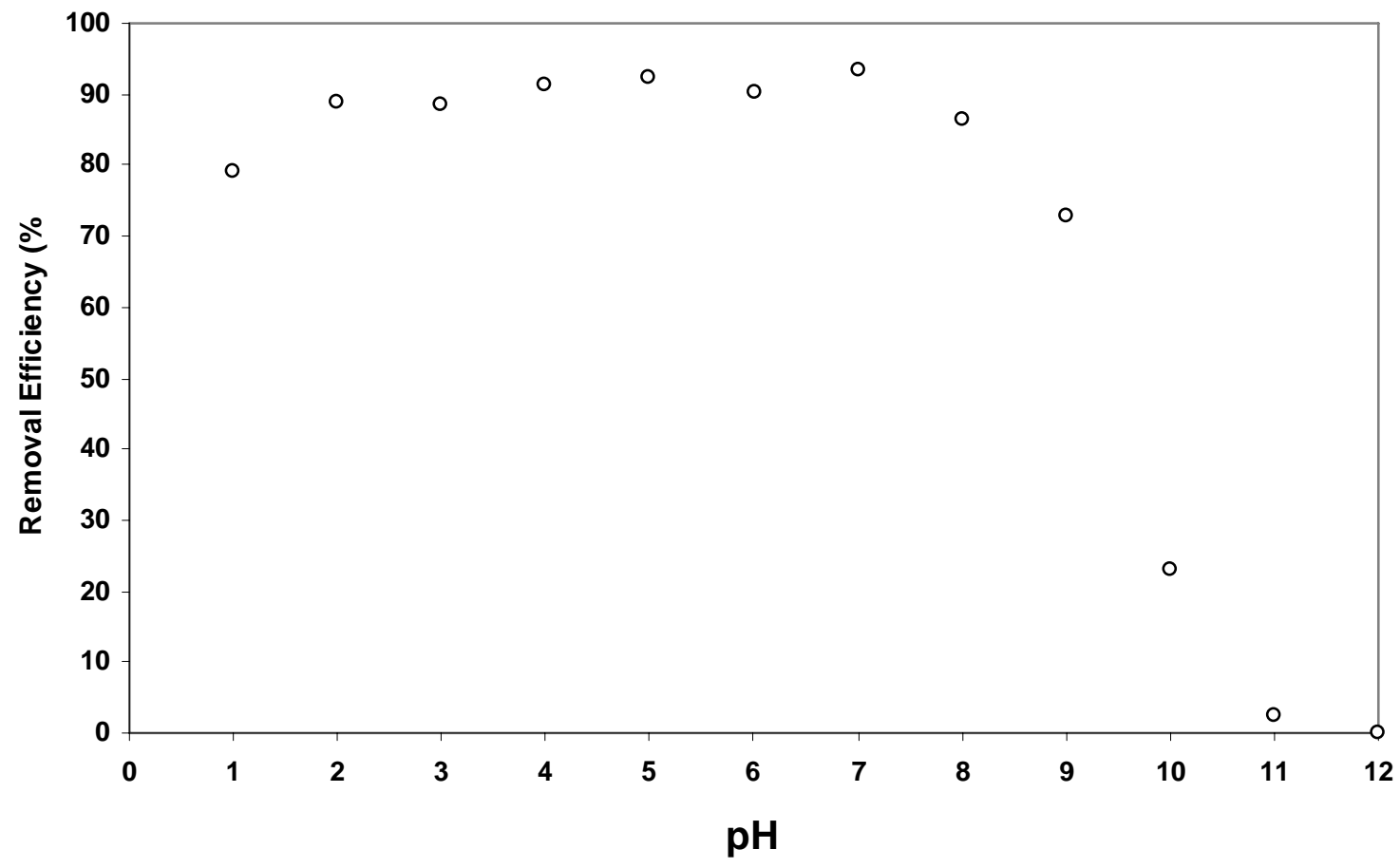

Figure 9. Effect of pH on selenite removal iron-coated Darco 12×20 GAC (0.1 M $\mathrm{FeCl}_{2}$ ) for the initial selenium concentration of $1 \mathrm{mg} / \mathrm{L}$. 


\subsection{Kinetic Studies}

The kinetic studies data revealed that 6-hour adsorption resulted in a removal efficiency as high as 90\%, and 48-hour adsorption was sufficient for reaching an equilibrium (Figure 10). The removal efficiencies at the equilibrium were $97.0 \%, 96.3 \%$ and $96.1 \%$ for initial selenium concentration of $0.5,1$ and $2 \mathrm{mg} / \mathrm{L}$, respectively. The adsorption capacity (i.e. $0.62,0.64$ and $0.61 \mathrm{mg}$-Se/g-adsorbent) did not change significantly for the three selenium concentrations examined. Kinetic studies were also carried out at different temperatures $\left(25,35\right.$ and $\left.45{ }^{\circ} \mathrm{C}\right)$ and the results are shown in Figure 11. As temperature increased from 25 to $45{ }^{\circ} \mathrm{C}$, adsorption capacity increased slightly from 0.64 to $0.66 \mathrm{mg}-\mathrm{Se} / \mathrm{g}$-adsorbent. The calculated kinetic rate constants for the three initial selenium concentrations and three temperatures are shown in Table 3. The adsorption rate was found to be enhanced by higher initial concentration. At $25^{\circ} \mathrm{C}$, the rate constant increased from 0.011 for initial Se concentration of $0.5 \mathrm{mg} / \mathrm{L}$ to 0.023 $\mathrm{g} /(\mathrm{min} \cdot \mathrm{mg})$ for initial Se concentration of $2 \mathrm{mg} / \mathrm{L}$. A previous study by Namasivayam and Prathap (2006) reported results for initial selenium concentration of $12.44 \mathrm{mg} / \mathrm{L}, q_{e}=$ $1.38 \mathrm{mg} / \mathrm{g}$ and $k=0.11 \mathrm{~g} /(\mathrm{mg} \cdot \mathrm{min})$ for a pretreated industrial solid waste $\mathrm{Fe}(\mathrm{III}) / \mathrm{Cr}$ (III) hydroxide as an adsorbent. The relatively faster kinetics can be attributed to the higher initial selenium concentration in their study..

Using equation (1), activation energy, $E_{a}$, was calculated to be $30.42 \mathrm{KJ} / \mathrm{mol}$ for the selenite adsorption reaction, which indicates the minimum energy necessary for the selenite adsorption reaction. 


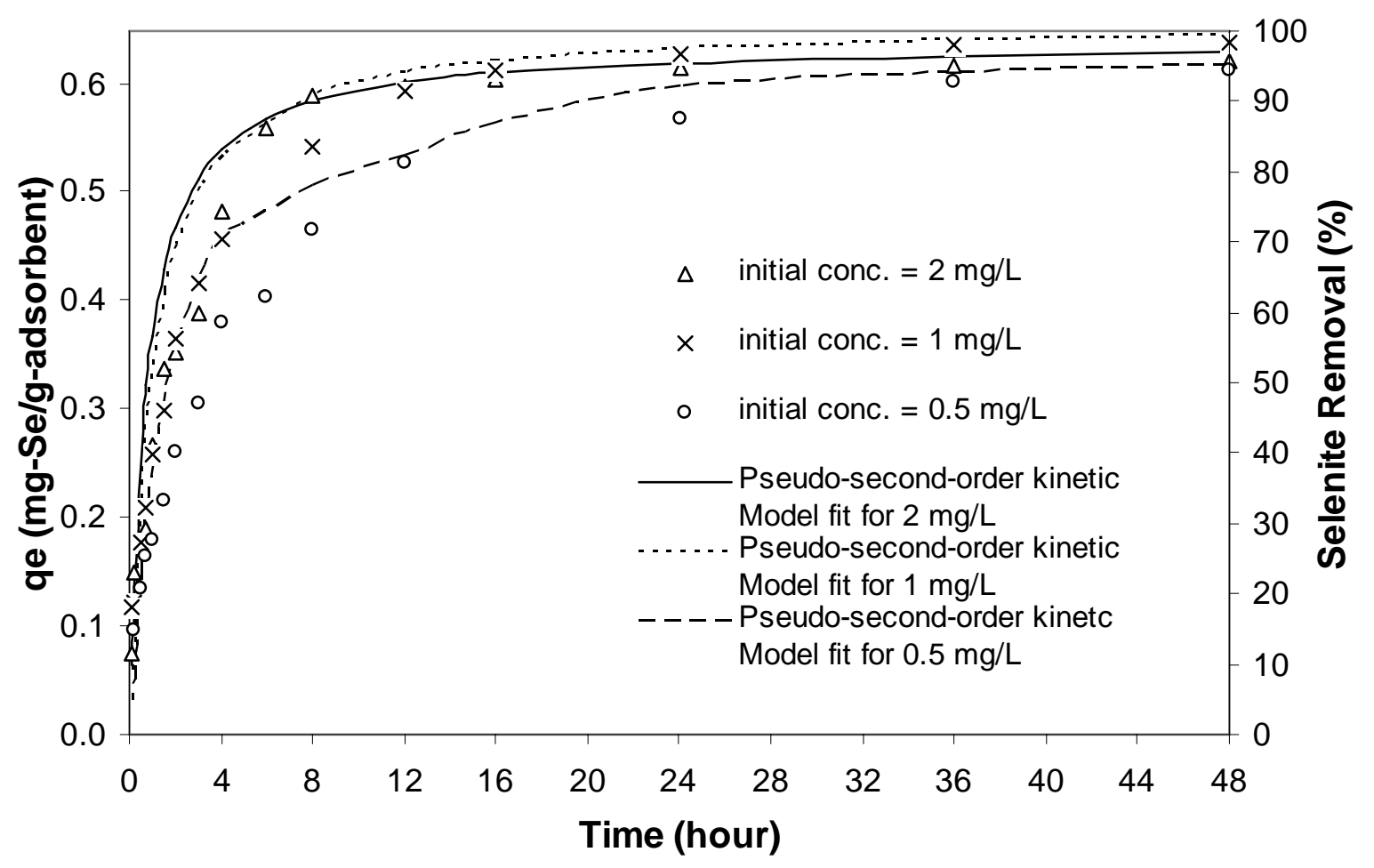

Figure 10. Adsorption kinetics and second-order kinetic model for selenium initial concentration of 2,1 and $0.5 \mathrm{mg} / \mathrm{L}$ at $\mathrm{pH} 5$ and $25^{\circ} \mathrm{C}$ with the adsorbent loading rate of 3, 1.5 and $0.8 \mathrm{~g} / \mathrm{L}$, respectively. 


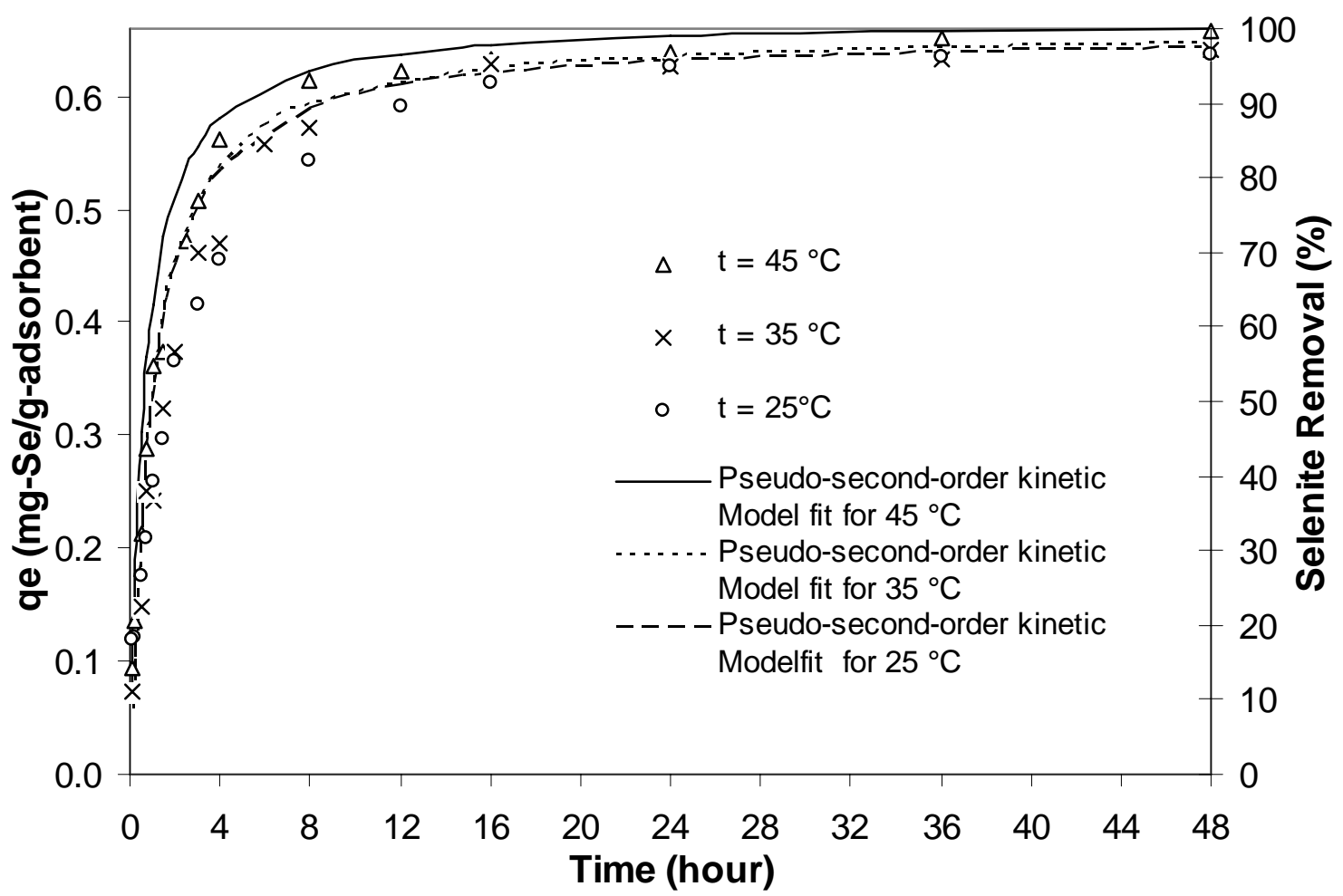

Figure 11. Adsorption kinetics and second-order kinetic model for selenium initial concentration of $1 \mathrm{mg} / \mathrm{L}$ at different temperatures with the adsorbent loading rat of $1.5 \mathrm{~g} / \mathrm{L}$ at $\mathrm{pH} 5$

Table 3. Values of the second-order adsorption rate constant $(k)$ and adsorption capacity $\left(q_{e}\right)$ for selenite adsorption unto iron-coated $\left(0.1 \mathrm{M} \mathrm{FeCl}_{2}\right)$ Darco 12x20 GAC in solutions with ionic strength of $0.1 \mathrm{M}$.

\begin{tabular}{ccccc}
\hline $\begin{array}{c}\text { Initial conc. } \\
(\mathbf{m g} / \mathbf{L})\end{array}$ & ${\mathbf{T e m p ~}\left({ }^{\circ} \mathbf{C}\right)}$ & $\begin{array}{c}\boldsymbol{k} /(\mathbf{m g} \cdot \mathbf{m i n}) \\
\mathbf{q} \text { (mg-Se/g- } \\
\text { adsorbent) }\end{array}$ & $\mathbf{R}^{\mathbf{2}}$ \\
\hline 0.5 & 25 & 0.011 & 0.64 & 0.9969 \\
1.0 & 25 & 0.018 & 0.66 & 0.9993 \\
2.0 & 25 & 0.023 & 0.64 & 0.9991 \\
1.0 & 35 & 0.019 & 0.66 & 0.9996 \\
1.0 & 45 & 0.027 & 0.67 & 0.9999 \\
\hline
\end{tabular}




\subsection{Adsorption Isotherms}

Selenite adsorption isotherms were developed for Darco $12 \times 20$ GAC treated with $0.1 \mathrm{M} \mathrm{FeCl}_{2}$. Figure 11 shows that adsorption capacity for the adsorbent reached 2.5 $\mathrm{mg}-\mathrm{Se} / \mathrm{g}$-adsorbent for initial selenium concentration of $2 \mathrm{mg} / \mathrm{L}$. The Langmuir isotherm model and Freundlich isotherm model were both applied to the selenite adsorption as shown in Figure 12. It indicated that the Langmuir model fitted the adsorption better at higher equilibrium concentration, which Freundlich model characterized it well at lower equilibrium concentration. According to the liner regression calculated for the two models, the Langmuir model showed a higher regression coefficient $(0.9958)$ rather than Freundlich model (0.9758). Figure 13 shows that the effect of temperature on the equilibrium adsorption capacity for initial selenium concentration of $2 \mathrm{mg} / \mathrm{L}$. The maximum adsorption capacity from calculation increased from 2.58 to $2.89 \mathrm{mg}-\mathrm{Se} / \mathrm{g}-$ adsorbent, as temperature increased from $25^{\circ} \mathrm{C}$ to $45^{\circ} \mathrm{C}$. 


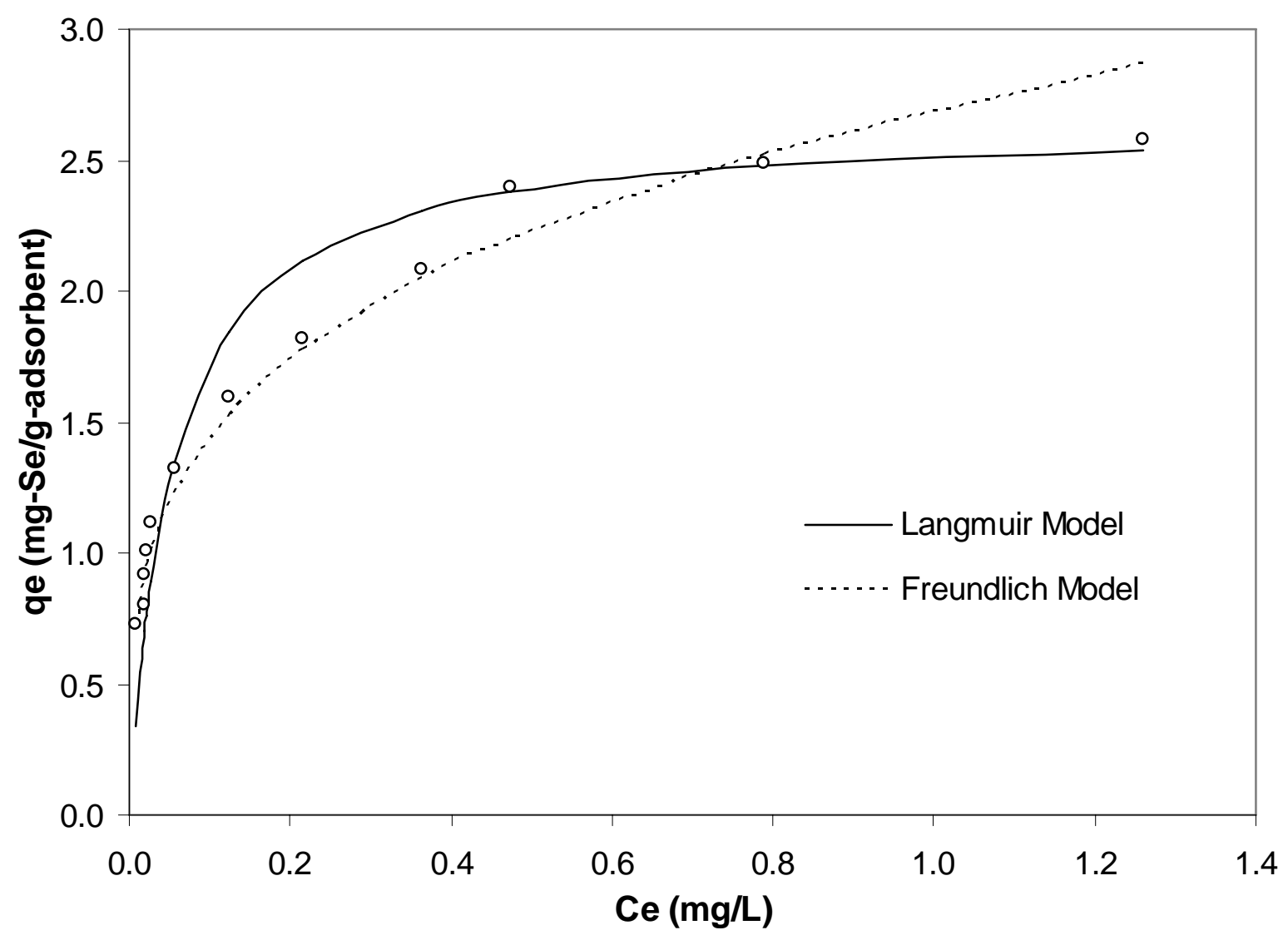

Figure 12. Selenite adsorption isotherms of $0.1 \mathrm{M}$ ferrous chloride coated Darco 12 $\times 20$ GAC for the initial selenium concentration of $2 \mathrm{mg} / \mathrm{L}$ at $\mathrm{pH} 5$ and $25^{\circ} \mathrm{C}$. 


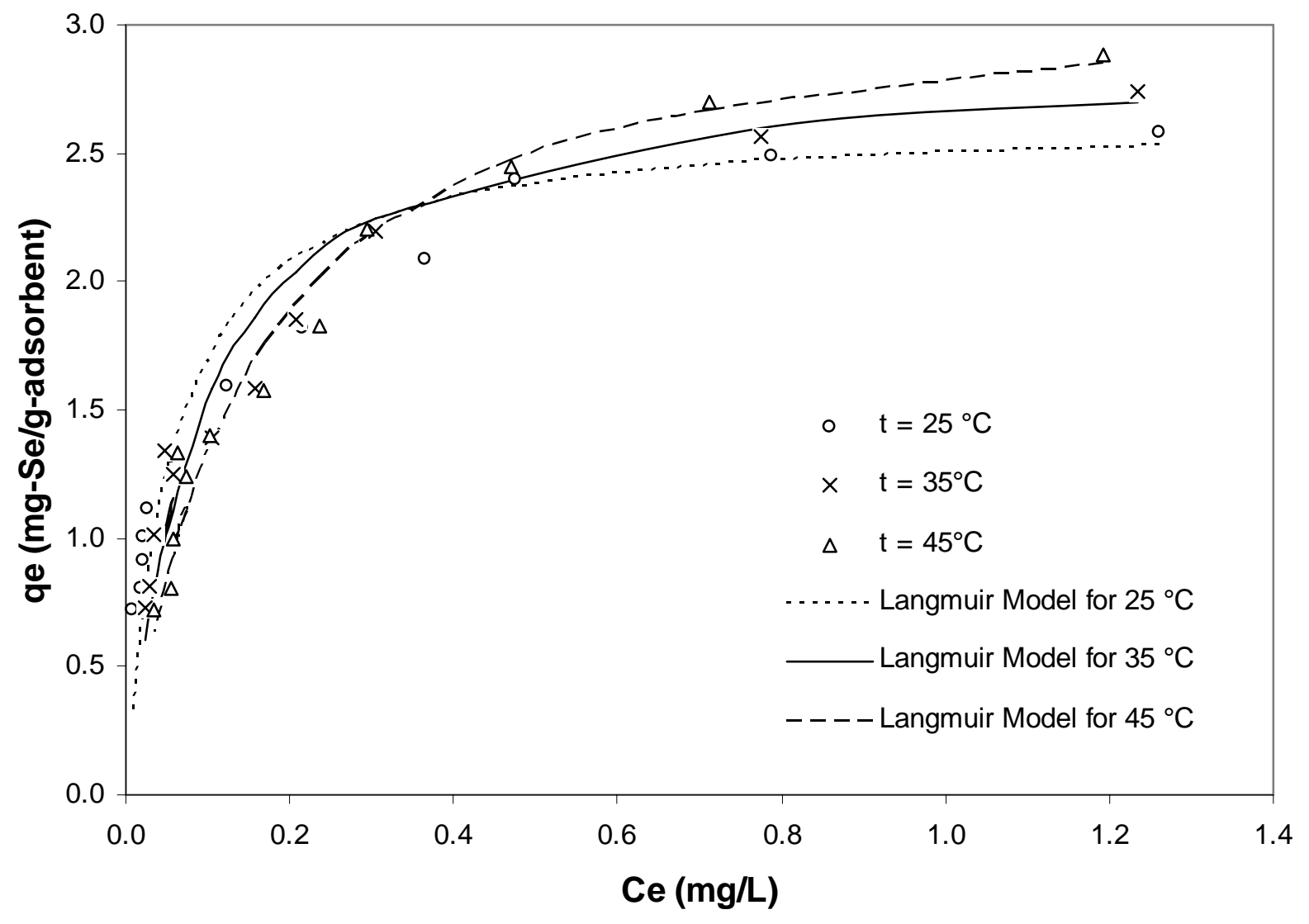

Figure 13. The Langmuir isotherm model of $0.1 \mathrm{M}$ ferrous chloride coated Darco 12 $\times 20$ GAC for initial selenium concentration of $2 \mathrm{mg} / \mathrm{L}$ at $\mathrm{pH} 5$ and different temperatures. 
Parameter values for the Langmuir model are presented in Table 4. The $q_{\max }$ value, $2.65 \mathrm{mg}$-Se/g-adsorbent, was much higher than the value previously reported (0.145 mg-Se/g-soil) for a tropical soil as an adsorbent for selenite removal by Goh and Lim (2004). The value of $b, 18.4 \mathrm{~L} / \mathrm{mg}$, was similar to those reported by Goh and Lim (17.3 L/mg) (2004), suggesting a similar affinity between selenite and the adsorbents. Namasivayam and Prathap (2006) reported that the values of $b$ and $q_{\max }$ were $0.28 \mathrm{~L} / \mathrm{mg}$ and $9.72 \mathrm{mg} / \mathrm{g}$ for a pretreated Fe (III)/Cr (III) hydroxide industrial solid waste, and 0.04 $\mathrm{L} / \mathrm{mg}$ and $3.78 \mathrm{mg} / \mathrm{g}$ for an untreated $\mathrm{Fe}$ (III)/Cr (III). The theoretical monolayer adsorption capacity, $q_{\max }$, of the treated and untreated industrial solid wastes are larger than the Fe-GAC developed in our study. These can be attributed to the larger surface areas provided by the powder form of the solid wastes. The substantially larger values of parameter $b$ suggest that selenite has a higher affinity to Fe-GAC over the industrial solid wastes. Table 4 also lists the values of $R_{L}$ for various initial selenium concentrations and temperatures. All the $R_{L}$ were between 0 and 1 in this study which suggests a favorable selenite adsorption onto the iron-coated GAC. The values that are all near zero indicate an irreversible isotherm (Moreira et al, 1998). The $\Delta G$ values are listed in Table 4 . The values were all negative for the three initial selenium concentrations and the three temperatures, indicating a spontaneous adsorption reaction between selenite and the FeGAC under the experimental conditions. 
Table 4. Parameter values of the Langmuir model for selenite adsorption with ionic strength of $0.1 \mathrm{M}$ at different temperatures.

\begin{tabular}{cccccccc}
\hline $\begin{array}{c}\text { Initial } \\
\text { conc. } \\
(\mathbf{m g} / \mathbf{L})\end{array}$ & $\begin{array}{c}\text { Ionic } \\
\text { Strength } \\
(\mathbf{M})\end{array}$ & $\begin{array}{c}\text { Temp } \\
\left({ }^{\circ} \mathbf{C}\right)\end{array}$ & $\begin{array}{c}\boldsymbol{q}_{\max }(\mathbf{m g}- \\
\text { Se/g- } \\
\text { adsorbent) }\end{array}$ & $\begin{array}{c}\boldsymbol{b} \\
(\mathrm{L} / \mathbf{m g})\end{array}$ & $\mathbf{R}^{2}$ & $\boldsymbol{R}_{\mathbf{L}}$ & $\begin{array}{c}\Delta \mathbf{G} \\
(\mathrm{KJ} / \mathrm{mol})\end{array}$ \\
\hline 2.03 & 0.1 & 25 & 2.65 & 18.4 & 0.9958 & 0.026 & -35.14 \\
2.06 & 0.1 & 35 & 2.74 & 11.44 & 0.9957 & 0.041 & -33.96 \\
2.06 & 0.1 & 45 & 2.89 & 7.49 & 0.9946 & 0.061 & -32.91 \\
\hline
\end{tabular}

Adsorption isotherms also were developed for solutions with different ionic strengths to determine the effect of ionic strength on the removal efficiency. Figure 14 shows the selenite adsorption at three levels of ionic strength $(0.01,0.1$ and $1 \mathrm{M})$. The results did not exhibit significant differences. The maximum adsorption capacity was approximately $2.55 \mathrm{mg}$-Se/g-adsorbent for all three ionic strengths. This is a macroscopic evidence that selenite adsorption onto iron-coated GAC formed inner-sphere complexes, since the inner sphere complex is not affected by ionic strength variations (Hayes and Leckie, 1987; Hayes et al., 1988). Values of the Langmuir isotherm parameters, $R_{L}$ and $\Delta G^{0}$ for the three ionic strengths are listed in Table 5. 


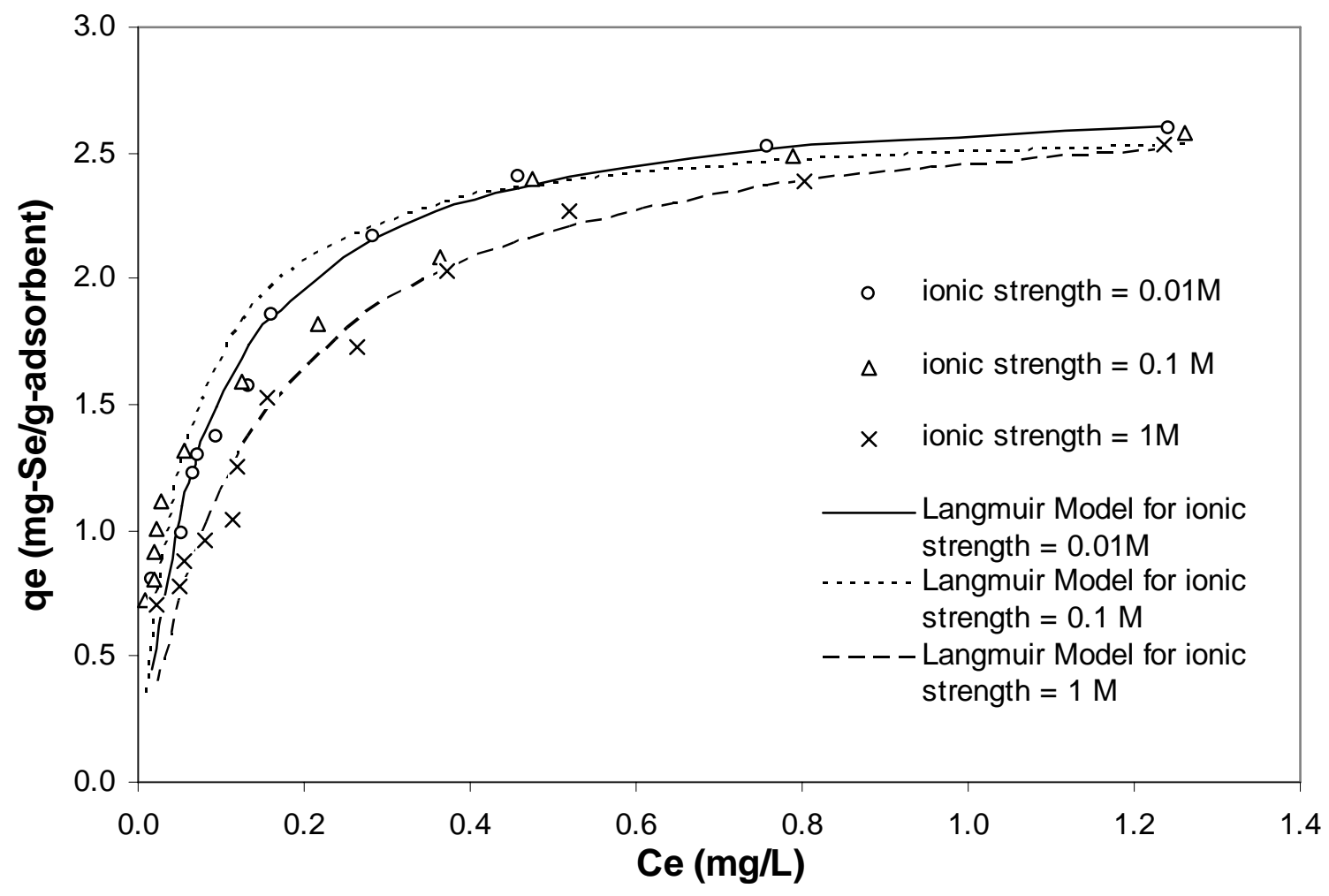

Figure 14. The Langmuir isotherm model of $0.1 \mathrm{M}$ ferrous chloride coated Darco 12 $\times 20$ GAC for initial selenium concentration of $1 \mathrm{mg} / \mathrm{L}$ with different ionic strengths at $\mathrm{pH} 5$ and $25^{\circ} \mathrm{C}$.

Table 5. Parameter values of the Langmuir model for selenite adsorption with different ionic strengths at $25^{\circ} \mathrm{C}$ and pH 5 .

\begin{tabular}{cccccccc}
\hline $\begin{array}{c}\text { Initial } \\
\text { conc. } \\
\text { (mg/L) }\end{array}$ & $\begin{array}{c}\text { Ionic } \\
\text { Strength } \\
(\mathbf{M})\end{array}$ & $\begin{array}{c}\text { Temp } \\
\left({ }^{\circ} \mathbf{C}\right)\end{array}$ & $\begin{array}{c}\boldsymbol{q}_{\max }(\mathbf{m g} \mathbf{~} \\
\text { Se/g- } \\
\text { adsorbent) }\end{array}$ & $\boldsymbol{b}(\mathbf{L} / \mathbf{m g})$ & $\mathbf{R}^{2}$ & $\boldsymbol{R}_{\mathbf{L}}$ & $\Delta \mathbf{G}$ \\
\hline 2.02 & 0.01 & 25 & 2.60 & 12.33 & 0.9980 & 0.039 & -34.15 \\
2.03 & 0.1 & 25 & 2.58 & 18.4 & 0.9958 & 0.026 & -35.14 \\
1.99 & 1 & 25 & 2.53 & 7.98 & 0.9941 & 0.064 & -32.86 \\
\hline
\end{tabular}




\subsection{Anion Competition Adsorption}

Figure 15 shows the results for the anion competitive adsorption for initial selenium concentration of $1 \mathrm{mg} / \mathrm{L}$. The presence of $\mathrm{SO}_{4}{ }^{2-}$ did not cause significant impact on the selenite adsorption. In the presence of $\mathrm{PO}_{4}{ }^{3-}, \mathrm{SiO}_{3}{ }^{2-}$ and $\mathrm{CO}_{3}{ }^{2-}$, the removal of selenite decreased to various degrees. The results can be explained using the triple layer model (Stumm and Morgan, 1995). Anions such as sulfate and selenate often are weakly bound with surface sites of metal hydroxides forming outer-sphere ( $\beta$-plane) surface complexes (Hayes et al., 1988). Adsorption of this sort is significantly affected by ionic strength. On the contrary, anions such as selenite and phosphate are bound relatively strongly with the surface sites. The complexes formation often takes place on inner-sphere (o-plane) and is barely affected by ionic strength. This explains why even the concentration of $\mathrm{PO}_{4}{ }^{3-}$ is as low as $1 \mathrm{mM}$, the removal efficiency of selenite decreases significantly, while sulfate did not compete with selenite effectively. For silicate and carbonate, there is no significant difference in selenite adsorption when the concentration of $\mathrm{SiO}_{3}{ }^{2-}$ and $\mathrm{CO}_{3}{ }^{2-}$ was low (i.e. $0.1 \mathrm{mM}$ ), but significant reduction of the removal efficiency occurred when the concentration was raised (i.e. $5 \mathrm{mM}$ ), especially for carbonate. The competition between these two anions and selenite possibly involved another reaction mechanism, surface accumulation/precipitation (Goh et al., 2004). The competitive anions may have accumulated or precipitated on the adsorbents surface, which promoted the formation of negatively charged surface sites and reduced surface potential. Therefore, the electorostatic repulsion between selenite and the negatively charge surface sites increased and thus reduced the adsorption of selenite. 


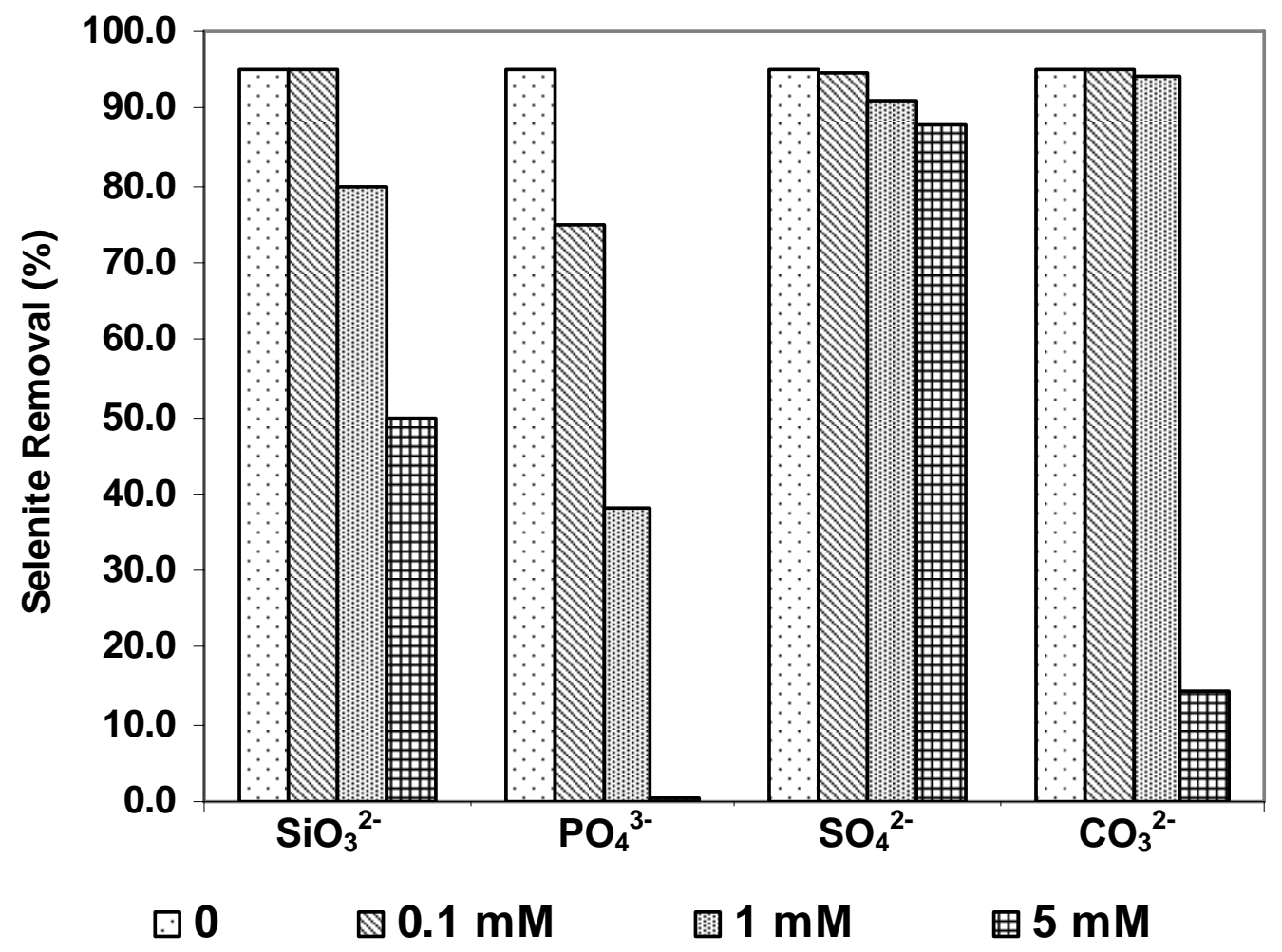

Figure 15. Effect of four oxyanions on selenite removal by iron-coated $\left(0.1 \mathrm{M} \mathrm{FeCl}_{2}\right)$ Darco 12×20 GAC coated after 24 hours at pH 5 and $25^{\circ} \mathrm{C}$. Initial selenium concentration is $1 \mathrm{mg} / \mathrm{L}$. 


\section{CHARPTER 5: CONCLUSION}

GACs were treated by ferrous chloride to prepare a novel adsorbent for selenite removal from aqueous solution in this study. SEM results showed that iron was coated onto the surface of GAC and some micropores and mesopores were blocked by the iron precipitates after the treatment. The EDS results indicated that the iron percentage coated on the surfaces of GAC increased along with the ferrous concentration applied in the coating process.

The iron-coated GACs were demonstrated to be efficient in removing selenite from aqueous solutions. Darco $12 \times 20 \mathrm{GAC}$ coated with $0.1 \mathrm{M} \mathrm{FeCl}_{2}$ was the most effective adsorbent among the GACs tested in this study. High selenite removal efficiencies (above 90\%) were observed in the $\mathrm{pH}$ range of $2-8$.

Adsorption kinetics showed that selenite removal efficiency reached more than $90 \%$ after 6-hour adsorption for initial selenium concentration of $2 \mathrm{mg} / \mathrm{L}$ and equilibrium was obtained after 48 hours. A pseudo-second-order kinetic model was applied to the adsorption data and it characterized the adsorption kinetics well $\left(R^{2}=0.9991\right)$.

Langmuir model was found to better characterize the adsorption data at the equilibrium than the Freundlich model. It was found that the ionic strength did not affect selenite adsorption, suggesting the formation of inner-sphere complexation between the selenite and the surface adsorption sites. The removal efficiency became slightly higher with the increase of temperature from 25 to $45^{\circ} \mathrm{C}$.

From the investigation of oxyanion competitive adsorption, the results indicated that sulfate barely affected the selenite adsorption. Other three anions (phosphate, silicate 
and carbonate) were found to compete with selenite and their impact on selenite adsorption varied with the type of the anions and their concentration.

Further research will focus on the adsorption mechanism studies by using FTIR, $\mathrm{XRD}$, and other surface analysis instruments. Adsorbents regeneration will be studied and developed. In addition, surface complex modeling for the surface reactions and numerical simulation of column setting will be conducted. 


\section{REFERENCES}

Abdullah, M. I., Shiyu, Z. and Mosgren, K. (1995) Arsenic and selenium species in the oxic and anoxic waters of the Oslofjord, Norway, Marine Pollution Bulletin, 31, 116126.

Ahlrichs, J. S.; Hossner, L. R. (1987) Selenate and selenite mobility in overburden by. saturated flow, Journal of Environment Quality, 16, 95-98.

Balistrieri, L.S., and Chao, T.T. (1987) Selenium adsorption by goethite, Soil Science Society of America Journal, 51, 1145-1151.

Bowen, H. J. M. (1996) Trace elements in biochemistry, Academic Press, San Diego.

Coleman, L., L.J. Bragg and R.B. Finkelman (1993) Distribution and mode of occurrence of selenium in US coals. Environmental Geochemistry and Health, 15(4), 215-227.

Crittenden, J.C., Trussell, R. R., Hand, D. W., Howe, K. J. and Tchobanoglous, G. (2005) 15: Adsorption, Water Treatment: Principles and Design, John Wiley and Sons: New York.

Davis, J. A., Leckie, J. O. (1980) Surface ionization and complexation at the oxide/water interface. 3. Adsorption of ions, Journal of Colloid and Interface Science, 74, 32-43.

Del-Debbio, J.A. (1991) Sorption of strontium, selenium, cadmium and mercury in soil, Radiochima Acta, 52/53, 181-186.

Devereln, S. J., Fio, J. L. and Dubrovsky, N. M. (1994) In: Selenium in the environment, Frankenberger, W. T.; Benson, S. Eds., Marcel Dekker INC., New York, 157-183. 
Federal Remediation Technologies Roundtable (2002) Remediation technologies screening matrix and reference guide, $4^{\text {th }}$ : 2.8.1 Inorganics, Washington D.C. http://www.frtr.gov/matrix2/section2/2_8_1.html.

Elrashidi, M. A., Adriano, D. C., Workman, S. M., Lindsay, W. L. (1987) Chemical equilibria of selenium in soils: A theoretical development, Soil Science, 144, 141-152.

Fio, J. L.; Fujii, R. (1990) Selenium speciation methods and application to soil saturation extracts from San Joaquin Valley, California, Soil Science Society of America Journal, 54, 363-369.

Frankenberger, W. T. Jr., Amerhein, C., Fan, T. W. M., Flaschi, D., Glater, J. Kartinen, E. Jr., Kovac, K., Lee, E., Ohlendorf, H. M., Terry, N. and Toto, A. (2004) Advanced treatment technologies in remediation of seleniferous drainage waters and sediments., Irrigation and Drainage Systems, 18, 19-41.

Gallup, D. L. (1996) In Proceedings of the 69th Water Environment Federation Conference, Dallas, TX; Water Environment Federation: Alexandria, VA, 447-453.

Garten, V., Weiss, D. and Willis, J. (1957) A newinterpretation of the acidic and basic structures in carbons, Aust. J. Chem., 10, 285.

Ghosh, M. M., Cox, C. D. and Yuan-pan, J.R. (1994) Adsorption of selenium on hydrous alumina, Environmental Progress, 13, 79-88.

Goh, K. and Lim, T. (2004) Geochemistry of inorganic arsenic and selenium in a tropical soil: effect of reaction time, $\mathrm{pH}$, and dompetitive anions on arsenic and selenium adsorption, Chemosphere, 55, 849-859. 
Gustafsson, J. P.; Johnsson, L. (1994) The association between selenium and humic substances in forested ecosystems - laboratory evidence, Applied Organometallic Chemistry, 8, 141-147.

Gu, Z., Fang, J. and Deng, B. (2005) Preparation and evaluation of GAC-Based IronContaining Adsorbents for Arsenic Removal, Environmental Science and Technology, $39,3833-3843$.

Hall, K., Eagleton, L., Aerivos, A., Vermeulen, T. (1996) Pore and solid diffusion kinetics fixed bed adsorption under constant pattern conditions, Industrial and Engineering Chemistry Fundamentals, 5, 212-213.

Hansen H.C.B., Koch C.B., Nancke-Krogh H., Borggaard O.K.; Sorensen J. (1996) Abiotic nitrate reduction to ammonium: key role of green rust. Environmental Science Technology 30, 2053-2056.

Hayes, K. and Leckie, J. (1987) Modeling ionic strength effects on cation adsorption at hydrous oxide/solution interfaces, Journal of Colloid and Interface Science, 115, 564572.

Hayes, K., Papelis, C., and Leckie, J. (1988) Modeling ionic strength effects of anion adsorption at hydrous oxide/solution interfaces, Journal of Colloid and Interface Science, 125, 717-726.

Hingston, F. J., Posner, A. M., and Quirk, J. P., (1974) Anion adsorption by goethite and gibbsite II. Desorption of anions from hydrous oxide surface, Journal of Soil Science. $25,16-26$.

Hoskins, J. and Karanfil T. (2002) Removal and sequestration of iodide using silverimpregnated activated carbon, Environmental Science and Technology, 36, 784-789. 
Ishizaki, C. and Marti, I. (1981) Surface oxide structures on a commercial activated carbon, Carbon, 19 (9), 409.

Jacobs L.W. (1989) Selenium in Agriculture and the Environment. American Society of Agronomy, Inc., Madison, WI.

Jang, M., Chen, W. and Cannon, F. (2008) Preloading Hydrous Ferric Oxide into Granular Activated Carbon for Arsenic Removal, Environmental Science and Technology, 42, 3369-3374.

Kenward, P. A., Fowle, D. A. and Yee, N. (2006) Microbial selenate sorption and reduction in nutrient limited systems, Environmental Science and Technology, 40, 3782-3786.

Kuan, W., Lo, S. Wang, M. and Lin, C. (1998) Removal of Se (IV) and Se (VI) from water by aluminum-oxice-coated sand, Water Research, 32 (3), 915-923.

Lakin, H. W. (1973) Selenium in our environment, Advances in Chemistry Series, 123, 96-111.

Lenntech (2007) Selenium, Lenntech Water treatment \& air purification Holding B.V.

Lo, S. L. and Chen, T. Y. (1997) Adsorption of Se (IV) and Se (VI) on an iron-coated sand from water, Chemosphere, 35 (5), 919-930.

Losi, M. E. and Frankenberger, W. T. Jr. (1997) Bioremediation of selenium in soil and water, Soil Science, 162 (10), 692-702.

Marinas, B. J., and Selleck, R. E. (1992) Reverse osmosis treatment of multicomponent electrolyte solutions, Journal of Membrane Science, 72, 211-229.

Masscheleyn, P. H., Patrick, W. H., (1993) Biogeochemical prosesses affecting selenium cycling in wetlands, Environmental Toxicology and Chemistry, 12, 2235-2243. 
Mavrov, V., Stamenov, S., Todorova, E., Chmiel, H., and Erwe, T. (2006) New hybrid electrocoagulation membrane process for removing selenium from industrial wastewater, Desalination, 201, 290-296.

Monteil-Rivera, F., Fedoroff, M., Jeanjean, J., Minel, L., Barthes, M. and Dumonceau, J. (2000) Sorption of selenite $\left(\mathrm{SeO}_{3}{ }^{2-}\right)$ on hydroxyapatite: An exchange process, Journal of Colloid and Interface Science, 221, 291-300.

Moreira, R.F.P.M., Peruch, M. G. and Kuhnen, N. C. (1998) Adsorption of textile dyes on alumina equilibrium studies and contact time effects, Brazilian Journal of Chemical Engineering, 15 (1),

MSE Technology Applications, Inc. (2001) Selenium treatment/removal alternatives demonstration project: Mine waste technology program activity III, project 20.

Namasivayam, C. and Prathap, K. (2006) Removal of selenite using 'waste' Fe (III)/Cr (III) hydroxide: Adsorption kinetics and isotherms, Toxicological and Environmental Chemistry, 88(1), 85-89.

Neal, R. H., Sposito, G.; Holtzclaw, K. M.; Traina, S. J. (1987a) Selenite adsorption on alluvial soils: I. Soil composition and pH effects, Soil Science Society of America Journal, 51, 1161-1165.

Ohlendorf, H. M. (1989) Selenium in agriculture and the environment, Soil Science Society of America, 133, Madison, WI.

Öhman, L. O. (1988) In: Metal speciation: theory, analysis and application, Lewis INC., Chelsea, 1-40. 
Pakula, M.; Biniak, S.; Swiatkowski, A. (1998) Chemical and electrochemical studies of interactions between iron (III) ions and an activated carbon surface, Langmuir, 14, 3082-3089.

Papelis, C., Brown, G. E., Parks, G. A., Leckie, J. O. (1995) X-ray adsorption spectroscopic studies of cadmium and selenite adsorption on aluminum oxides, Langmuir, 11, 2041-2048.

Papelis, C., Roberts, P. V., Leckie, J. O. (1995) Modeling the rate of cadmium and selenite adsorption on micro-and mesoporous transition aluminas, Environmental Science and Technology, 29, 1099-1108.

Parfitt, RL. (1978) Anion adsorption by soils and aoil materials, Adv. Agron., 30, 1-50.

Parida, K. M., Gorai, B., Das, N. N. and Rao, S. B. (1997) Studies on ferric oxide hydroxides: III Adsorption of selenite on different forms of iron oxyhydroxides, Journal of Colloid and Interface Science, 185, 355-362.

Peak, D. and Sparks, D. L. (2002) Mechanisms of selenate adsorption on iron oxides and hydroxides, Environmental Science and Technology, 36, 1460.

Reddy, K. J., Zhang, Z., Blaylock, M. J., Vance, G. F. (1995) Method for detecting selenium speciation in groundwater, Environmental Science and Technology, 29, 1754-1759.

Saeki,K., Matsumoto, S.; Tatsukawa, R. (1995) Selenite adsorption by manganese oxides, Soil Science, 160, 265-272.

Séby, F., Potin-Gautier, M., Lespes, G. and Astruc, M. (1997) Selenium speciation in soils after alkaline extraction, Science of the Total Environment, 207, 81-90. 
Séby, F., Potin-Gautier, M., Giffaut, E. and Donard, O. F. X. (1998) Assessing the speciation and the biogeochemical processes affecting the mobility of selenium from a geological repository of radioactive wastes to the biosphere, Analysis, 26, 193-198.

Stumm, W., Huang, C. P., and Jenkins, S. R. (1970) Specific chemical interaction affecting the stability of dispersed systems, Croatica Chemica Acta, 42, 223.

Swinden, L. (2007) Report on toxicity of sediments produced during channel dredging in port Phillip Bay, Department of primary industries annual report.

Tamari, Y. (1998) Methods of Analysis for the Determination of Selenium in Biological, Geological and Water Samples, Environmental Chemistry of Selenium, ed. By Frankenberger Jr., W. T. and Engberg, R. A., Marcel Dekker, Inc.

Todini Co s.p.a. (2006) Chemical product based on selenium, http://www.todiniandco.com/products/selenium/index.html (accessed Sep. 2007)

USDOA (2002) Tracking the pathways and anticipating impacts of selenium, http://www.srs.fs.usda.gov/news/96

USEPA (2006) Consumer Factsheet on: Selenium, National Primary Drinking Water Regulations, http://www.epa.gov/safewater/dwh/c-ioc/selenium.html (accessed Nov., 2006)

USEPA (2007) Mine Waste Technology: success stories, http://www.epa.gov/hardrockmining/ (accessed Jan, 2007)

USEPA (2003) Mountaintop Mining/Valley Fills in Appalachia: Draft Programmatic Environmental Impact Statement, U.S. Environmental Protection Agency. USEPA (1998) Standard Methods for the Examination of Water and Wastewater, 3500Se-C Colorimetric Method, U.S. Environmental Protection Agency. USEPA (2006) 
Technical Factsheet on: Selenium, National Primary Drinking Water Regulations, http://www.epa.gov/safewater/dwh/t-ioc/selenium.html (accessed Nov., 2006)

Vaughan Jr., R. L., Reed, B. E. (2005) Modeling As (V) removal by a iron oxide impregnated activated carbon using the surface complexation approach, Water Research, 39, 1005-1014.

Vesper, D. J., Bryant, G. and Ziemkiewicz, P. F. (2004) A preliminary study on the speciation of selenium in a West Virginia watershed, 2004 National Meeting of American Society of Mining and Reclamation, April 18-24, Lexington, KY.

Vuori, E., Vääriskoski, J., Hartikainen, H.; Kumpulainen, J.; Aarnio, T.; Niinivaara, K. (1994) A long-term study of selenate sorption in Finnish cultivated soils, Agr. Ecosyst. Environ., 48, 91-98.

White, A. F., Dubrovsky, N. M. (1994) In: Selenium in the environment, Frankenberge, W. T., Benson, S. Eds. Mareel Dekker Inc., New York, 185-221.

WV Geological and Economic Survey. Trace Elements in West Virginia Coals, http://www.wvgs.wvnet.edu/www/datastat/te/index.htm (accessed Dec., 2005)

Yang, L., Wu, S. and Chen, J. (2007) Modification of Activated Carbon by Polyaniline for Enhanced Adsorption of Aqueous Arsenate, Industrial and Engineering Chemistry Research, 46, 2133-2140.

Yantasee, W., Lin, Y., Fryxell, G., Alford, K., Busche, B. and Johnson, C. (2004) Selective removal of copper (II) from aqueous solutions using fine-grained activated carbon functionalized with amine, Industrial and Engineering Chemistry Research, $24,2759-2764$. 


\section{VITA}

Ning Zhang was born in Shenyang, Liaoning Province, People's Republic of China. She enrolled in Dalian University of Technology, Dalian, Liaoning Province in Sep. 2000 and received her Bachelor Degree in Environmental Science and Technology in Jul. 2004. After graduation, she was admitted into West Virginia University in Aug. 2005, studying for her Master degree in Civil and Environmental Engineering. She worked under the advisement of Dr. Lian-shin Lin and her work focused on selenium removal by adsorption using iron coated granular activated carbon. 